\title{
Plastic or glass: a new environmental assessment with a marine litter indicator for the comparison of pasteurized milk bottles
}

\author{
Roberta Stefanini ${ }^{1} \cdot$ Giulia Borghesi $^{2} \cdot$ Anna Ronzano $^{2} \cdot$ Giuseppe Vignali $^{1}$ (D)
}

Received: 10 March 2020 / Accepted: 30 July 2020 / Published online: 14 August 2020

(C) The Author(s) 2020

\begin{abstract}
Purpose Today plastic is the most used material for food packaging, but its incorrect disposal is creating environmental issues to oceans, soil and air. Someone believes that the solution is to ban plastic and substitute it with glass packaging. Is it the right choice? This study aims at comparing the environmental impact of bottles made of PET, R-PET, non-returnable glass and returnable glass in order to understand which is the most environmental friendly packaging solution.

Methods A literature analysis on the environmental impact of glass and PET bottles is carried out, taking into account their production, transport and disposal phase. Then, an environmental assessment of PET, R-PET, glass and returnable glass bottles, used to package 11 of pasteurized milk, has been carried out using the life cycle assessment methodology and a new indicator. Inventory data were provided by an important milk processing and packaging factory located in Italy. Results were estimated using some relevant impact categories of the ReCiPe 2016 MidPoint $(\mathrm{H})$ method, then a marine litter indicator (MLI) has been proposed in order to evaluate the polluting potential of milk bottles dispersed into the Mediterranean Sea.

Results and discussion LCA results show that R-PET bottle gives the lowest contribution to global warming, stratospheric ozone depletion, terrestrial acidification, fossil resource scarcity, water consumption and human carcinogenic toxicity, followed by PET bottle, returnable glass bottle, and finally non-returnable glass bottle. Glass is the worst packaging option because of high energy demand in the bottle production and its weight and in the transport phase. Some improvements can be obtained with returnable glass, but even if we consider that a bottle could be reused eight times, results are not comparable to the PET or R-PET bottles used only once. However, according to the MLI, returnable glass bottles become the first option, because a lot of plastic bottles could potentially be dispersed into the sea.

Conclusions The substitution of plastic with glass does not help to reduce the GWP and others LCI categories, while could contribute to reduce the marine litter: overall it is important to dispose correctly packaging materials, investing in recycling and reusing. In particular, great improvements can be obtained using bottles made with recycled materials, as R-PET. In conclusion, it is necessary to disadvantage waste dispersion, giving incentives to returnable packaging and raising people awareness of environmental problems.
\end{abstract}

Keywords Life cycle assessment $\cdot$ Milk $\cdot$ Glass bottles $\cdot$ PET $\cdot$ Food packaging $\cdot$ Recycling $\cdot$ Plastic litter

\section{Introduction}

The global plastic production continued to increase rapidly because it is versatile, hygienic, flexible, highly durable and suitable for many applications (Plastic Europe, 2019). Plastic

Communicated by: Carlo Ingrao

Giuseppe Vignali

giuseppe.vignali@unipr.it

1 Department of Engineering and Architecture, University of Parma, Parco Area delle Scienze 181/A, 43124 Parma, Italy

2 Cipack Center, University of Parma, Tecnopolo, Parco Area delle Scienze PAD 33, 43124 Parma, Italy is often used in food packaging, thanks to its ability to preserve food and today numerous packaging as containers, bottles, trays and cups are made of it (Robertson, 2012). However, the great amount of their production causes environmental problems all over the world in every steps of its life as extraction, production, consumption and disposal. First of all, traditional plastics are made with the fossil-based process: non-renewable energy is consumed in the fossil fuel extraction and a lot of greenhouse gases are emitted in the atmosphere contributing to the climate change. Moreover, at the end of its life, not all the plastic is recycled: part of it ends up in landfills, polluting the soil, or in the incinerator, polluting again the atmosphere, but in the worst case it is thrown away in the environment, into the rivers as and oceans (Vitale, et al., 
2018). Plastic can take thousands of years to decompose: bottles, bag, cups, thrown into the sea break down, thanks to the waves, into little pieces smaller than $5 \mathrm{~mm}$ called micro-plastic, that are very dangerous to the maritime flora and fauna (Min, et al., 2020).

For all these reasons, it is a matter of urgency to find a solution to the plastic pollution. Someone believes that the best way is to ban the use of plastic packaging, creating new materials or substituting it with glass or paper. Others researchers are against the abolition of plastic and believe that common people assumed that the alternative materials are better than plastic basing their idea only on hearsay (Ragaert, 2019). Which is the less impactful packaging material? Is glass better than plastic from an environmental point of view? The answer can be found thanks to an objective comparison between packaging materials, considering not only the quantity of materials needed but also how many resources as water, soil, energy are used in production, thus verifying the effects they have on the environment. Life cycle assessment (LCA) is one of the most adopted method to assess the environmental impacts associated with the life cycle stages of a product or a process, from raw material extraction, product's manufacture, distribution and use, up to the final disposal (European Commission, 2003). However, based on existing LCIA methods, it is difficult to evaluate the marine and terrestrial litter because no impact category takes into account these issues. For this purpose, based on some published studies dealt with the same issues (Civancik-Uslu, et al., 2019), in our study we will make a proposal of a marine litter lndicator (MLI). Our ultimate goal is to understand which packaging material is more environmental friendly between plastic and glass, considering all the phases, starting from the production up to the final disposal. In particular, four different containers for 11 of milk are considered: a PET bottle, a recycled PET (R-PET) bottle, a non-returnable glass bottle and a returnable glass bottle. The study was carried out in collaboration with an important factory located in Italy expert in milk processing and packaging, responsible to provide most of the inventory data for the LCA.

\subsection{Literature analysis}

Some research are available on the environmental impact of milk packaging and processing (Meneses, et al., 2012, Djekic, et al., 2014, Bertolini, et al., 2016, Boesen, et al., 2019, Nutter, et al., 2013, Thoma, et al., 2013, Jungbluth, et al., 2018, Laca, et al., 2020), but no LCA study compares milk packaged in glass and in plastic bottles. Some research instead compare the environmental impact of plastic and glass packaging solutions for water, juice, carbonated soft drink and contrast media (Amienyo, et al., 2013, Saleh, 2015, Pasqualino, et al., 2011, Dhaliwal, et al., 2014). Other papers explore the impact of glass bottles depending on their way of disposal, in particular recycling or reuse (Landi, et al., 2019, Mata \& Costa, 2001). Details about these works are reported in Table 1.

Based on the liquid product's life cycle taken in consideration in these articles, packaging is almost always the most impactful stage, regardless of the material used. This is true for soft carbonated drinks in 0.751 glass bottles, in 0.331 aluminium cans, in 0.5 and 21 PET bottles, for water in 1.51 PET bottles and for juice in 11 carton, where also the transport phase is impactful. On the other hand, in the life cycle of beer in 0.331 aluminium cans, the most impacting phase is the production of barley, followed by packaging (Pasqualino, et al., 2011), and the same results should be expected considering the impact of milk packaged in a glass or plastic bottle.

Overall, the analysed works highlight that, if the volumetric content of the packaging increases, the environmental impact of the packaged product decreases. For example, the GWP of 21 PET bottle beverages is less than half of that of 0.51 bottles (Amienyo, et al., 2013). The same result is confirmed by studies conducted on contrast liquids packaging, water in PET and glass bottles, beer in cans and juice in cardboard (Dhaliwal, et al., 2014, Pasqualino, et al., 2011). This is due to the reduction of packaging materials needed per unit of product when a larger format is used: logically, only one bottle is used to package 1.51 of soft drink, and requires the use of less material than three 0,51 bottles used to pack the same quantity.

Established that packaging has a significant impact on the life cycle of most liquid products, it is important to compare the different options of packaging materials in order to identify the least impacting during production, transport, use and disposal. Based only on packaging production phase, scientific research agree that glass bottles are less environmental friendly if compared to PET, HDPE, cardboard, PP bottles or aluminium cans, in particular according to the GWP and CED impact categories (Amienyo, et al., 2013, Pasqualino, et al., 2011). No considerations about food waste and its impact have been done for these shelf stable liquid, while in the case of milk this could be very important (Manfredi, et al., 2015). As regards the transport phase, it contributes about $3 \%$ of the total impact of the liquid product. Also, in this phase, glass is the most impactful material, due to its high weight and dimensions (Amienyo, et al., 2013). Finally, considering different type of waste disposal such as recycling, incineration and landfill, the polymer bottle results better than glass for the environment as far as the disposal method used is concerned: glass is the most impactful packaging material for all types of drinks according to Cumulative Energy Demand and Global Warming Potential (Pasqualino, et al., 2011). Packaging materials recycling is thus highly recommended, mainly due to the saving of virgin material (Saleh, 2015); however, glass containers have another way of disposal: the reuse. A comparison between the recycling and reuse scenario for wine glass bottles in Italy shows that reuse could be a promising solution to reduce the environmental impact of 0.751 glass bottles: it allows to recover the entire bottle, 
Table 1 Research about the comparison between the environmental impact of plastic and glass or non-reusable and reusable glass

\begin{tabular}{|c|c|c|c|c|c|c|}
\hline Authors & Title & Area & $\begin{array}{l}\text { System } \\
\text { boundaries }\end{array}$ & $\begin{array}{l}\text { Functional } \\
\text { unit }\end{array}$ & Method & GWP RESULTS ( $\mathrm{kg} \mathrm{CO} 2 \mathrm{eq} / \mathrm{l})$ \\
\hline $\begin{array}{l}\text { Mata and } \\
\text { Costa, } \\
(2001)\end{array}$ & $\begin{array}{l}\text { Life cycle assessment of } \\
\text { different reuse } \\
\text { percentages for glass } \\
\text { beer bottles }\end{array}$ & Portugal & $\begin{array}{l}\text { From } \\
\text { cradle } \\
\text { to grave }\end{array}$ & $\begin{array}{l}1000 \\
\text { bottles } \\
\text { of } 0.331\end{array}$ & $\begin{array}{l}\text { BUWAL Database Critical water and } \\
\text { air volume, human toxicity, global } \\
\text { warming, ozone depletion, } \\
\text { acidification, eutrophication, } \\
\text { photochemical ozone creation e final } \\
\text { solid waste }\end{array}$ & $\begin{array}{c}1^{\circ} \text { cycle: returnable: } 0.13 ; \\
\text { non-returnable: } 0.126^{\circ} \\
\text { cycle: returnable: } 0.28 \\
\text { non-returnable: } 0.59\end{array}$ \\
\hline $\begin{array}{l}\text { Pasqualino } \\
\quad \text { et al., } \\
\text { (2011) }\end{array}$ & $\begin{array}{l}\text { The carbon foot print and } \\
\text { energy consumption of } \\
\text { beverage packaging } \\
\text { selection and disposal }\end{array}$ & Spain & $\begin{array}{l}\text { From } \\
\text { cradle } \\
\text { to grave }\end{array}$ & $\begin{array}{l}\text { Packaging } \\
\text { to } \\
\text { contain } \\
11 \text { of } \\
\text { beverage }\end{array}$ & Ecoinvent v2.1 database GWP, CED & $\begin{array}{l}\text { Juice in aseptic carton }(1 \mathrm{l}) \text { : } \\
0.113 \text {; beer in aluminium can } \\
(330 \mathrm{ml}): 0.826 \text {; water in } \\
\text { PET bottle (1.5 1): } 0.078\end{array}$ \\
\hline $\begin{array}{l}\text { Amienyo, } \\
\text { et al. } \\
\text { (2013) }\end{array}$ & $\begin{array}{l}\text { Life cycle environmental } \\
\text { impacts of carbonated } \\
\text { soft drinks }\end{array}$ & UK & $\begin{array}{l}\text { From } \\
\text { cradle } \\
\text { to grave }\end{array}$ & $\begin{array}{l}11 \text { of } \\
\text { carbon- } \\
\text { ated soft } \\
\text { drink }\end{array}$ & $\begin{array}{l}\text { Gabi 4.3, CCaLC v2.0, Ecoinvent } \\
\text { (2010). CML } 2001 \text { method GWP, } \\
\text { primary energy demand, abiotic } \\
\text { depletion, acidification, human } \\
\text { toxicity, fresh water and marine } \\
\text { aquatic toxicity, photochemical } \\
\text { oxidant creation potentials, } \\
\text { eutrophication, terrestrial } \\
\text { ecotoxicity }\end{array}$ & $\begin{array}{l}\text { Soft drink in glass bottle } \\
\quad(0.75 \text { 1): } 0.555 \text { Aluminium } \\
\text { can }(0.33 \text { 1): } 0.312 ; \text { PET } \\
\text { bottle }(0.51): 0.293 ; \text { PET } \\
\text { bottle }(21): 0.151\end{array}$ \\
\hline $\begin{array}{l}\text { Saleh } \\
\quad(2015)\end{array}$ & $\begin{array}{l}\text { Comparative life cycle } \\
\text { assessment of } \\
\text { beverages packages in } \\
\text { Palestine }\end{array}$ & Palestine & $\begin{array}{l}\text { From } \\
\quad \text { cradle } \\
\text { to grave }\end{array}$ & $\begin{array}{l}10001 \text { of } \\
\text { beverage }\end{array}$ & $\begin{array}{l}\text { Impact } 2002+\text { method Water } \\
\text { consumption, non-renewable } \\
\text { energy, solid waste, human toxicity, } \\
\text { respiratory effects, terrestrial } \\
\text { acidification, global warming po- } \\
\text { tential }\end{array}$ & $\begin{array}{l}\text { Glass bottles (0.33 1): } 2.57 \text {; } \\
\text { Aluminium cans (0.33 1): } \\
\text { 0.46; PET bottles (2 1): } 0.044\end{array}$ \\
\hline $\begin{array}{l}\text { Dhaliwal } \\
\text { et al., } \\
2015\end{array}$ & $\begin{array}{l}\text { Glass or Plastic: An } \\
\text { environmental LCA } \\
\text { and related economic } \\
\text { impact of contrast } \\
\text { media packaging }\end{array}$ & USA & $\begin{array}{l}\text { From } \\
\text { cradle } \\
\text { to grave }\end{array}$ & $\begin{array}{l}\text { Bottle of } \\
100 \mathrm{ml}\end{array}$ & $\begin{array}{l}\text { ReCiPe (H/A), Cumulative Energy } \\
\text { Demand } \\
\text { Climate change, ozone depletion, } \\
\text { human toxicity, photochemical } \\
\text { oxidant formation, particulate matter } \\
\text { formation, ionizing radiation, } \\
\text { ecosystem quality, resources, } \\
\text { cumulative energy demand }\end{array}$ & $\begin{array}{l}\text { Polymeric vial: } 1.81 \text {; Glass vial: } \\
\quad 4.01\end{array}$ \\
\hline $\begin{array}{l}\text { Landi } \\
\text { et al., } \\
2019\end{array}$ & $\begin{array}{l}\text { Analysing the } \\
\text { environmental } \\
\text { sustainability of glass } \\
\text { bottles reuse in an } \\
\text { Italian wine } \\
\text { consortium }\end{array}$ & Italy & $\begin{array}{l}\text { From gate } \\
\text { to grave }\end{array}$ & $\begin{array}{l}\text { Wine in } \\
\text { glass } \\
\text { bottle of } \\
0.751\end{array}$ & $\begin{array}{l}\text { SimaPro 8.05.13 Ecoinvent } 3.1 \\
\quad \text { ReCiPe midpoint method - } \\
\text { Hierarchist }(\mathrm{H}) 18 \text { impact categories }\end{array}$ & Reuse: -0.0156 ; Recycle: 1.21 \\
\hline
\end{tabular}

if undamaged, avoiding the use of virgin glass, in contrast with the recycle scenario in which $42.5 \%$ by weight of bottle is made with virgin glass. According to this research, the most impacting phases in reuse are the sterilization and drying of returnable bottles, while in recycling the melting of the glass and the formation of the bottle consume large quantities of heat and electricity (Landi, et al., 2019).

Established that bottle glass reuse is better than recycling from an environmental point of view, it remains to understand for how many cycles it is convenient to adopt this disposal method. According to Amienyo et al., by reusing the glass bottle only once, the impact can be reduced by $40 \%$. However, the savings percentage does not increase with the number of reuses: the benefit is not so significant after the second cycle, until it completely stabilizes after the eighth, because of the significant increase in the transport and washing impacts. Results show that if the glass bottle is reused three times, it has an impact similar to aluminium cans or 0.51 PET bottles. The best solution is to reuse glass bottles 1-5 times, depending on the cost-effectiveness of the operation (Amienyo, et al., 2013). The reuse of glass bottles would allow a substantial decrease in the environmental impact; however, this material does not result as the best option for beverage packaging. In fact, the same study shows that if the recycling rate of 0.51 PET bottles is increased from 24 to $60 \%$, the total GWP of carbonated drinks would be drastically reduced: the GWP of drinks packaged in 0.51 PET would be half of that for drinks in aluminium cans. Glass bottles should 
be reused at least 20 times in order to obtain similar results. Moreover, 21 PET bottles have the lowest impact on primary energy demand; abiotic depletion; acidification; fresh water and marine aquatic toxicity; photochemical oxidant creation potentials, even if they have an high value on the eutrophication potential; human toxicity; and ozone depletion potential (Saleh, 2015, Amienyo, et al., 2013, Dhaliwal, et al., 2014).

However, none of the presented studies take into consideration the marine and terrestrial litter, which are the currently discussed issues caused by plastics. In Italy, about 53 thousand tons of plastic are poured every year into the Mediterranean Sea: $78 \%$ comes from coastal activities, $18 \%$ from fishing activities and $4 \%$ is transported by rivers (WWF, 2019). According to a specific study, $65 \%$ of plastic floats on the surface for a year, while $24 \%$ returns to the beach and $11 \%$ is disposed on the seabed: after hundreds of years plastic begins to break up (Min, et al., 2020), thus forming micro plastics, highly harmful to marine flora and fauna, which in the Mediterranean reach concentrations of $20 \mathrm{~g} / \mathrm{m}^{3}$ (Liubartseva, et al., 2018). According to a research made on Italian coasts, plastic waste constitutes $81.2 \%$ of the waste found on beaches (29\% of which comes from food packaging), followed by glass/ceramic (7.3\%), metal (3.7\%), paper (2.8\%), rubber, textiles or wood. In particular, plastic bottles for drinks, including caps and rings are the most common disposable plastic products that pollute the coastlines (Legambiente, 2019).

Based on these data, the importance of quantifying the water pollution caused by packaging materials dispersed into the seas is evident. Currently, no software used for the LCA method takes into consideration indicators to quantify the plastic litter of different packaging. In scientific literature, there is only a research proposing such kind of indicator, but it refers exclusively to shopping bags used in Spain and quantifies their marine and land littering potential (Civancik-Uslu, et al., 2019). This indicator is therefore very specific, but can be taken as a starting point for the development of a method applicable to others contexts, materials and packaging.

Our study takes into account all these premises. In the next chapter the functional unit, the system boundaries, scope and inventory analysis of the LCA using SimaPro 9.0 are presented. Moreover, in order to give our contribution to new researches about this topic, a MLI is proposed. Finally, the main outcomes are discussed and future research outlined.

\section{Methods}

\subsection{Life cycle assessment}

The environmental performances of four packaging systems were evaluated along their life cycle, starting from the extraction of raw materials up to the product disposal at the end of its life. LCA methodology follows principles and guidelines of ISO 14040:2006, ISO 14044:2006 and it is composed by four main steps: goal and scope definition, inventory analysis, impact assessment and interpretation.

The goal of the study is to evaluate and compare the environmental impact of four different solutions to package 11 of pasteurized milk. The considered packaging systems are bottles made of virgin PET, recycled PET (R-PET), non-returnable and returnable glass. SimaPro 9.0 is the LCA software used to model the system with EcoInvent 3.5 database. ReCiPe MidpointHierarchist $(\mathrm{H})$ method is applied to estimate the environmental impacts. The most significant indicators for this study were considered: global warming $\left(\mathrm{kg} \mathrm{CO}_{2} \mathrm{eq}\right)$, stratospheric ozone depletion ( $\left.\mathrm{kg} \mathrm{CFC}_{11} \mathrm{eq}\right)$, terrestrial acidification $\left(\mathrm{kg} \mathrm{SO}_{2}\right.$ eq), fossil resource scarcity (kg oil eq), water consumption $\left(\mathrm{m}^{3}\right)$ and human carcinogenic toxicity (kg 1.4-DCB).

The functional unit (FU) is defined as the reference unit for which the inventory data are normalized. The functional unit of this study is a container for 11 of pasteurized milk considering then the bottle, the cap and label, and all the activities and materials connected to the packaging activities.

According to primary data provided by an Italian company, who packages water in returnable and non-returnable glass bottles (Lauretana, 2020), in Italy a returnable glass bottle can have 8 cycles before being damaged because of scuffing. Therefore, for returnable glass solution, 8 usages and 7 cycles or reuses are considered in this work; the first cycle is considered as that of non-returnable glass bottles except the recycling/incineration scenario, since the bottle is reused, while the glass bottle reuses are considered 7 times. Each of the seven cycles includes transport to collection centre, transport from the collection centre to food companies (all included in the "reuse scenario" phase), washing phase, new cap, new label, new auxiliary materials, production (sterilization, filling and packaging) and distribution. Finally, the EoL phase considers the packaging materials and glass bottle disposal at the end of eighth cycle.

The system boundaries follow a "cradle to grave" approach considering the extraction of packaging raw materials, manufacturing processes and end of life (EoL), including transport activities required at different levels of the life cycle. According to the EPD Product Category Rules (PCR) for packaging materials, the production of milk was excluded, as well as the product use phase since it is assumed that the users' behaviours are variable and not measurable (Bertoluzzi, 2019). Environmental Product Declaration (EPD) is an example of type III environmental declaration according to ISO 14025:2006 and it is based on an LCA study; the PCR explain guidelines to conduct an LCA analysis in order to compile an EPD and to compare with others similar environmental declaration (Strazza, et al., 2016).

The system boundaries are described in Fig. 1.

The extraction of raw materials includes the manufacturing of the FU's component parts: 
Primary packaging including bottles (for PET and R-PET solutions preforms were included), high-density polyethylene (HDPE) and steel caps, polypropylene (PP) labels

Secondary and tertiary packaging materials: low-density polyethylene (LDPE) bags and stretch wrap, corrugated board and linerboard for interlayer pads and boxes, wood pallets

The manufacture phase of PET and R-PET bottles includes blowing preforms, bottle filling and packaging. The same phase for glass bottles considers bottle sterilization, filling and packaging. In addition, the transport of raw materials and packaged products from a food company to distribution centres and retails stores have been taken into account. In EoL stage, according to the Italian Sustainability Reports (COREPLA, 2018, COREVE, 2019), three waste treatments were considered: recycling, landfill and incineration with energy recovery; furthermore, for returnable glass bottles, an EoL scenario of eight reuse cycles was considered. Collected data are related to 2018. Cut-off criteria are less than $2 \%$ : the dyes in plastic bottles are not considered because they are present in $1.4 \%$ of the total weight.

\subsubsection{Inventory analysis and data collection}

The inventory analysis allows to quantify energy and resources consumption and environmental releases associated with the entire life cycle of the examined systems. Four different companies were contacted to obtain data about composition, amount and weight of primary, secondary and tertiary packaging, used energy and distances. The analysed food company has two factories respectively responsible for similar percentage of the packaged product production. Therefore, the same percentages were adopted for the supply of raw materials and distribution of the finished product for the first (FF1) and second (FF2) food factory. The average weights of the packaging materials were obtained by directly weighting the empty containers provided by the different industries and are shown in Table 2.

Energy and resources data related to primary packaging equipment are reported in Table 3. As far as plastic bottles are concerned, data refer to the consumption of electricity associated with preform production (with $1.7 \%$ of external recycling), blowing, filling and packaging. In addition, consumptions of food steam associated with sterilization and decontamination with hydrogen peroxide are considered. For the glass bottle, decontamination treatment with hydrogen peroxide, consumption of steam food and electricity during washing and filling operation are taken into account. Electricity country mix with medium voltage datasets is used for all data related to energy consumption.

With regard to secondary and tertiary packaging:

PET and R-PET preforms are contained in octabins reaching a maximum of 9570 preforms.

Glass bottles are transported on a wood pallet wrapped with LDPE shrink film of four layers of 176 containers with 4 PP interlayer pads, one corrugated board top tray. The total is 704 bottles.

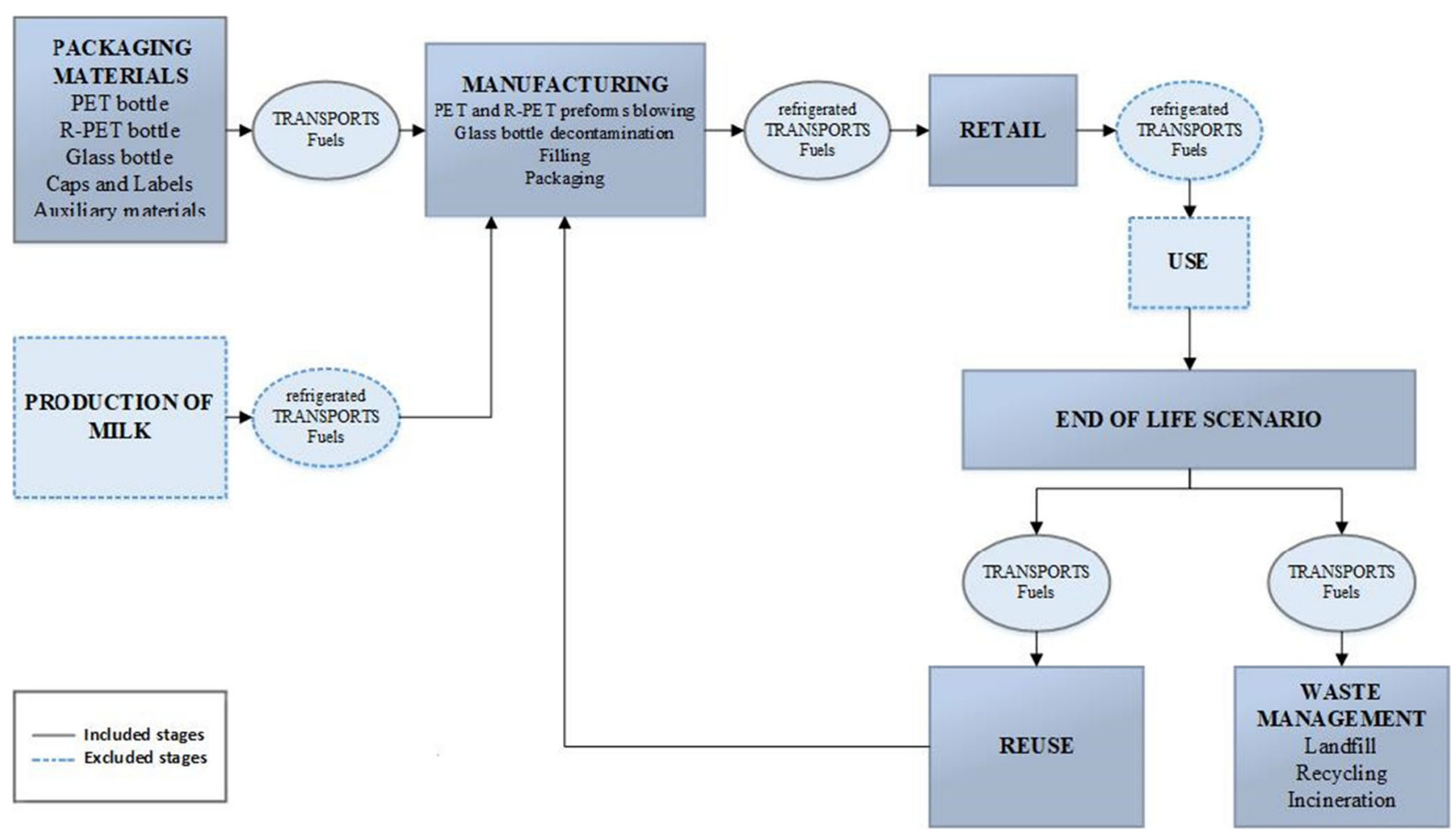

Fig. 1 System boundaries 
Table 2 Characteristics of investigated packaging systems for FU

\begin{tabular}{llllll}
\hline $\begin{array}{l}\text { Packaging } \\
\text { Type }\end{array}$ & Material & $\begin{array}{l}\text { Height } \\
(\mathrm{mm})\end{array}$ & $\begin{array}{l}\text { Diameter } \\
(\mathrm{mm})\end{array}$ & $\begin{array}{l}\text { Weight } \\
(\mathrm{g})\end{array}$ & $\begin{array}{l}\text { Source of LCI } \\
\text { data }\end{array}$ \\
\hline Bottle & $\begin{array}{l}\text { PET } \\
\text { R-PET (50\% recycled) } \\
\text { Glass (62.5\% recycled white } \\
\text { glass) }\end{array}$ & 249.7 & 84.5 & 22 & Ecoinvent v.3.5 \\
& $\begin{array}{l}\text { HDPE } \\
\text { Cap }\end{array}$ & 18 & 86 & 400 & Ecoinvent v 3.5 \\
Label & PP & 8.65 & 44.75 & 3.43 & Ecoinvent v. 3.5 \\
\hline
\end{tabular}

HDPE and steel caps are contained in a LDPE bags and corrugated boards in a group of 20 boxes for HDPE and 30 for steel one, allowing each wood pallet wrapped with LDPE shrink film to transport 3000 caps.

PP labels are transported on a wood pallet wrapped with LDPE shrink film in 48 LDPE bags, with 4 carton board interlayer pads, reaching a total of about 20,000 pieces.

Milk packaged with glass bottles are contained in 76 corrugated cardboard boxes in a group of 6 , with 4 paperboard interlayer pads, allowing each wood pallet wrapped with LDPE shrink film to transport 456 bottles.

Milk packaged with PET and R-PET bottles are contained in 40 LDPE shrink-wrapped packs, with 4 corrugated board interlayer pads, reaching a total amount of 480 bottles for wood pallet wrapped with LDPE shrink film.

It is assumed that the food company buys plastic preforms from a local Italian producer, who buys PET and R-PET granules from chemical industries located in the south of Asia and Europe,
Table 3 Energy and resources uses of primary packaging equipment for $1 \mathrm{FU}$

\begin{tabular}{|c|c|c|c|c|}
\hline $\begin{array}{l}\text { Packaging } \\
\text { type }\end{array}$ & $\begin{array}{l}\text { Manufacturing } \\
\text { stage }\end{array}$ & Amount & $\begin{array}{l}\text { Measurement } \\
\text { unit }\end{array}$ & EcoInvent data \\
\hline Preform & Production & $6.6 \mathrm{E}-03$ & $\mathrm{kWh}$ & $\begin{array}{l}\text { Electricity, medium voltage }\{\mathrm{IT}\} \mid \text { market for } \\
\quad \mid \text { cut-off, } S\end{array}$ \\
\hline $\begin{array}{l}\text { Plastic } \\
\quad \text { bottle- } \\
\text { FF1 }\end{array}$ & $\begin{array}{l}\text { Blowing, filling } \\
\text { and packaging }\end{array}$ & $3.3 \mathrm{E}-03$ & $\mathrm{kWh}$ & $\begin{array}{l}\text { Electricity, medium voltage }\{\mathrm{IT}\} \mid \text { market for } \\
\mid \text { cut-off, S }\end{array}$ \\
\hline $\begin{array}{l}\text { Plastic } \\
\text { bottle- } \\
\text { FF2 }\end{array}$ & $\begin{array}{l}\text { Blowing, filling } \\
\text { and packaging }\end{array}$ & $3.9 \mathrm{E}-03$ & $\mathrm{kWh}$ & $\begin{array}{l}\text { Electricity, medium voltage }\{\mathrm{IT}\} \mid \text { market for } \\
\mid \text { cut-off, } \mathrm{S}\end{array}$ \\
\hline \multirow[t]{3}{*}{$\begin{array}{l}\text { Plastic } \\
\text { bottle }\end{array}$} & $\begin{array}{l}\text { Sterilization food } \\
\text { steam }\end{array}$ & $1.98 \mathrm{E}-03$ & $\mathrm{~kg}$ & $\begin{array}{l}\text { Heat, from steam, in chemical industry } \\
\{\text { RER }\} \mid \text { market for heat, from steam, in } \\
\text { chemical industry | cut-off, } S\end{array}$ \\
\hline & $\begin{array}{l}\text { Decontamination } \\
\text { with } \mathrm{H}_{2} \mathrm{O}_{2}\end{array}$ & $8.73 \mathrm{E}-05$ & $\mathrm{~L}$ & $\begin{array}{l}\text { Hydrogen peroxide, without water, in } 50 \% \\
\text { solution state }\{\text { RER }\} \mid \text { market for } \\
\text { hydrogen peroxide, without water, in } 50 \% \\
\text { solution state } \mid \text { cut-off, } \mathrm{S}\end{array}$ \\
\hline & & & & $\begin{array}{l}\text { Tap water }\{\text { Europe without Switzerland }\} \mid \\
\text { tap water production, conventional } \\
\text { treatment } \mid \text { cut-off, S }\end{array}$ \\
\hline \multirow[t]{5}{*}{$\begin{array}{l}\text { Glass } \\
\text { bottle }\end{array}$} & $\begin{array}{l}\text { Filling and } \\
\text { packaging }\end{array}$ & $5.95 \mathrm{E}-04$ & $\mathrm{kWh}$ & $\begin{array}{l}\text { Electricity, medium voltage }\{\mathrm{IT}\} \mid \text { market for } \\
\quad \mid \text { cut-off, } \mathrm{S}\end{array}$ \\
\hline & Washing & $2.98 \mathrm{E}-01$ & $\mathrm{~L}$ & $\begin{array}{l}\text { Tap water }\{\text { Europe without Switzerland }\} \mid \\
\text { market for } \mid \text { cut-off, } S\end{array}$ \\
\hline & $\begin{array}{l}\text { Decontamination } \\
\text { with } \mathrm{H}_{2} \mathrm{O}_{2}\end{array}$ & $8.73 \mathrm{E}-05$ & $\mathrm{~L}$ & $\begin{array}{l}\text { Hydrogen peroxide, without water, in } 50 \% \\
\text { solution state }\{\text { RER }\} \mid \text { market for } \\
\text { hydrogen peroxide, without water, in } 50 \% \\
\text { solution state | cut-off, S }\end{array}$ \\
\hline & & & & $\begin{array}{l}\text { Tap water }\{\text { Europe without Switzerland }\} \mid \\
\text { tap water production, conventional } \\
\text { treatment } \mid \text { cut-off, S }\end{array}$ \\
\hline & $\begin{array}{l}\text { Sterilization food } \\
\text { steam }\end{array}$ & $1.98 \mathrm{E}-03$ & $\mathrm{~kg}$ & $\begin{array}{l}\text { Heat, from steam, in chemical industry } \\
\{\text { RER }\} \mid \text { market for heat, from steam, in } \\
\text { chemical industry | cut-off, } S\end{array}$ \\
\hline
\end{tabular}


respectively. As regards the glass bottles, HDPE caps, PP labels, it can be considered that the manufacturing companies are located in Italy, while the steel caps come from Germany. As regards the secondary and tertiary packaging materials, it was assumed that octabins, which contains polymer preforms, cardboard boxes and interlayer pads, shrink wraps, come from Italy. Finally, it was assumed that pallets are returned to the distribution centre with a generic distance of $50 \mathrm{~km}$. Moreover, a refrigerated transport for the packaged product for both primary and secondary distribution was assumed:

The primary distributions were assumed a 7.5-16 ton, EURO5 truck and distances of $198 \mathrm{~km}, 346 \mathrm{~km}$ between the two production sites of packaged milk to the distribution centre located in north and centre of Italy respectively.

The secondary distributions were considered a 3.5-7.5 ton, EURO5 truck and an average distance of $45 \mathrm{~km}$ between distribution centres to retailers located in Italy.

The details about transport activities are shown in Table 4.

Data of plastic and glass bottles recycled, incinerated with energy recovery or disposed in landfill were obtained from Sustainability Reports of specific Italian Consortia (COREPLA, 2018, COREVE, 2019, RICREA, 2020, CONAI, 2019, RILEGNO, 2019, COMIECO, 2019) as shown in Table 5. With regard to the municipal incineration of waste, the benefits resulting from energy recovery in incineration, as electric and thermal energy, are taken into account using the Ecoinvent v. 3.5 database.

Nowadays, in Italy, the reuse scenario for returnable glass bottles is not so widespread. However, primary data from industrial washer are collected and rearranged in order to quantify the reuse phase using an automatic equipment. In addition, the transport of the used glass bottles to the collection centre (average distance of $50 \mathrm{~km}$ by means of 16-32 tons, EURO5 truck) is considered. Details about the amount of consumption resources are reported in Table 6. Furthermore, it was assumed a generic distance of $100 \mathrm{~km}$ by $16-32$ tons, EURO5 truck for distances between municipal solid waste collection centre and recycling, incineration and landfill sites. It was considered the same transport from the collection centre to the two food factories equal to the primary distribution transport distances. In the reuse scenario, it was considered that glass bottle is used eight times, according to primary data provided by Lauretana company (Lauretana, 2020), and confirmed by a previous research which demonstrated that the benefit of reusing do not increase after the eighth cycle (Amienyo, et al., 2013). Therefore, it is assumed that after the eighth cycle a returnable glass bottle is disposed as a nonreturnable glass bottle.

\subsection{Proposal for marine litter indicator}

Our MLI proposal starts from the work of Civancik-Uslu et al. (Civancik-Uslu, et al., 2019); however, their parameters have been modified and adapted to our case study. Italy is the reference context, and the considered milk bottles materials are
$100 \%$ PET, $100 \%$ RPET, non-returnable glass and returnable glass. For each of these configurations, we intend to evaluate the impact caused by the possible dispersion of empty milk bottles in the Mediterranean Sea, without considering their labels and caps. In the analysis, the following relative factors $\left(F_{i}\right)$ have been considered as relevant.

- The quantity of bottles dispersed in the environment (F1)

The yearly production of pasteurized milk in Italy is known (CLAL, 2018). It is possible to estimate how many bottles of 11 are necessary for its packaging and calculate the potential number of milk bottles dispersed in the environment. In fact, thanks to the annual sustainability reports of some Italian consortia (COREPLA, 2018, COREVE, 2019), it is possible to know how many plastic and glass materials have been dispersed each year. Moreover, the glass bottle dispersion is estimated to be $10 \%$ for each cycle in the returnable glass bottle system (Il Sole 24 ore, 2017).

Based on this data, while the indicator of the aforementioned article (Civancik-Uslu, et al., 2019) takes into account the overall yearly packaging production, our proposal considers that the marine litter depends only on the quantity of the packaging uncollected and consequently dispersed in the environment. Furthermore, it does not take into account the surface of the packaging, but its (1 1).

\section{- Incentives for returnable bottles (F2)}

In the case of milk bottles, we supposed that their price is not influencing its conservation: unlike the shopping bag that could be used as a waste bin liner, milk bottles are difficulty reused for other purposes. However, a factor widely used in countries such as Germany, and still used less in Italy, could be important to consider: the return of money every time a bottle is brought back to the distributor. For instance, the Italian incentive is 0.25 euros for each glass bottle returned (Il ministro dell'ambiente, 2017) and 0.05 euros for the PET and R-PET bottle, according to primary data provided by CORIPET (CORIPET, 2020). We can assume that, the higher the value of the incentive is, the lower is the risk that citizens will abandon bottles into the environment.

\section{- Material weight (F3)}

A light container can be easily carried by wind and waves, and thus could pollute the water. This parameter is therefore closely connected with the density of the used material.

- Time of degradation (F4)

This factor indicates the persistence of the bottle in the environment: a plastic bottle takes up to 400 years to degrade, 
Table 4 Transport type and distances for primary, secondary and tertiary packaging

\begin{tabular}{|c|c|c|c|}
\hline Packaging type & Transport type & Origin & $\begin{array}{l}\text { Distance } \\
(\mathrm{km})\end{array}$ \\
\hline \multicolumn{4}{|l|}{ Primary packaging } \\
\hline \multirow[t]{2}{*}{ Granule PET } & Transoceanic ship & Asia & 11,820 \\
\hline & $\begin{array}{l}\text { Truck ( } 32 \text { tons, } \\
\text { Euro 5) }\end{array}$ & & 165 \\
\hline Granule R-PET & $\begin{array}{l}\text { Truck ( } 32 \text { tons, } \\
\quad \text { Euro } 5 \text { ) }\end{array}$ & Europe & 1116 \\
\hline Preform- to FF1 & \multirow{2}{*}{$\begin{array}{l}\text { Truck ( } 32 \text { tons, } \\
\quad \text { Euro 5) }\end{array}$} & \multirow[t]{2}{*}{ Italy } & 633 \\
\hline Preform-to FF2 & & & 62.4 \\
\hline Glass bottle- to FF1 & \multirow{2}{*}{$\begin{array}{l}\text { Truck ( } 32 \text { tons, } \\
\text { Euro } 5\end{array}$} & \multirow[t]{2}{*}{ Italy } & 151 \\
\hline Glass bottle- to FF2 & & & 520 \\
\hline HDPE cap-to FF1 & \multirow{2}{*}{$\begin{array}{l}\text { Truck ( } 32 \text { tons, } \\
\quad \text { Euro 5) }\end{array}$} & \multirow[t]{2}{*}{ Italy } & 539 \\
\hline HDPE cap-to FF2 & & & 78 \\
\hline Steel cap_- to FF1 & \multirow{2}{*}{$\begin{array}{l}\text { Truck ( } 32 \text { tons, } \\
\text { Euro 5) }\end{array}$} & \multirow[t]{2}{*}{ Germany } & 1087 \\
\hline Steel cap_ to FF2 & & & 1555 \\
\hline PP label- to FF1 & \multirow{3}{*}{$\begin{array}{l}\text { Truck ( } 32 \text { tons, } \\
\text { Euro 5) }\end{array}$} & \multirow[t]{3}{*}{ Italy } & 307 \\
\hline PP label— to FF2 & & & 382 \\
\hline Secondary and tertiary packaging & & & \\
\hline Octabin-to FF1 & \multirow{2}{*}{$\begin{array}{l}\text { Truck ( } 32 \text { tons, } \\
\text { Euro } 5 \text { ) }\end{array}$} & \multirow[t]{2}{*}{ Italy } & 396.4 \\
\hline Octabin-to FF2 & & & 967 \\
\hline $\begin{array}{l}\text { Cardboard interlayer pad for packaged plastic bottle (PET and } \\
\text { R-PET) - to FF1 }\end{array}$ & \multirow[t]{2}{*}{$\begin{array}{l}\text { Truck ( } 32 \text { tons, } \\
\text { Euro } 5 \text { ) }\end{array}$} & \multirow[t]{2}{*}{ Italy } & 55 \\
\hline $\begin{array}{l}\text { Cardboard interlayer pad for packaged plastic bottle (PET and } \\
\text { R-PET) - to FF2 }\end{array}$ & & & 611 \\
\hline $\begin{array}{l}\text { Cardboard box, interlayer pad for packaged glass bottle - to } \\
\text { FF1 }\end{array}$ & \multirow[t]{2}{*}{$\begin{array}{l}\text { Truck ( } 32 \text { tons, } \\
\text { Euro } 5 \text { ) }\end{array}$} & \multirow[t]{2}{*}{ Italy } & 146 \\
\hline $\begin{array}{l}\text { Cardboard box, interlayer pad for packaged glass bottle- to } \\
\text { FF2 }\end{array}$ & & & 491 \\
\hline LDPE shrink wrap-to FF1 & \multirow{2}{*}{$\begin{array}{l}\text { Truck (32 tons, } \\
\quad \text { Euro 5) }\end{array}$} & \multirow[t]{2}{*}{ Italy } & 230 \\
\hline LDPE shrink wrap - to FF2 & & & 469 \\
\hline
\end{tabular}

while the glass bottle takes about 4000 years (WWF, 2018, Makesense, 2018).

The likelihood that milk bottles contributes for the plastic litter in the Mediterranean Sea is therefore directly proportional to the potential number of dispersed milk bottles and the time the several materials take to degrade. Conversely, it is inversely proportional to incentives given for the returnable bottle and to the weight of the dispersed bottles. In agreement with the work of Civancik-Uslu (Civancik-Uslu, et al., 2019)

Table 5 Italian waste treatment pathways

\begin{tabular}{llll}
\hline Packaging materials & Recycle (\%) & Incineration (\%) & Landfill (\%) \\
\hline Plastic & 44.5 & 43 & 12.5 \\
Glass & 76.2 & 0 & 23.8 \\
Paper and carton board & 81.1 & 7.6 & 11.3 \\
Steel & 78.6 & 0 & 21.4 \\
Wood & 63.8 & 2.4 & 33.8 \\
\hline
\end{tabular}

we kept all the indexes as a ratio between the value assumed by the current scenario and the maximum value it could assume among the several analysed options.

The MLI could thus be expressed as follows:

$\mathrm{MLI}=\frac{F 1^{f 1} * F 4^{f 4}}{F 2^{f 2} * F 3^{f 3}}$

where,

MLI = marine litter indicator

$\mathrm{F} 1=$ number of dispersed containers

Table 6 Energy and resources uses for reuse stages for $1 \mathrm{FU}$

\begin{tabular}{llll}
\hline Reuse stage & Resource & Amount & Measurement Unit \\
\hline \multirow{3}{*}{ Washing and drying } & Electricity & $2.94 \mathrm{E}-04$ & $\mathrm{kWh}$ \\
& Water & $2.78 \mathrm{E}-01$ & 1 \\
& Industrial steam & $7.93 \mathrm{E}-03$ & $\mathrm{~kg}$ \\
& Soda & $1.26 \mathrm{E}-03$ & 1 \\
\hline
\end{tabular}


F2 = incentive for returnable bottles

$\mathrm{F} 3$ = weight of the packaging material

$\mathrm{F} 4=$ material degradation time

$\mathrm{f} 1, \mathrm{f} 2, \mathrm{f} 3, \mathrm{f} 4 \mathrm{~s}=$ weighting factors, currently equal to 1 . In addition, in section 3.2, a possible weighting is carried out

$\mathrm{F} 1, \mathrm{~F} 2, \mathrm{~F} 3, \mathrm{~F} 4$ = dimensionless factors, calculated as follow:

$F 1=\frac{B_{d}}{\left(B_{d}\right)_{\max }}$

where,

$B_{d}=$ potential number of dispersed milk bottles (bottles)

$\left(B_{d}\right)_{\max }=$ maximum number of dispersed milk bottles (bottles)

$\mathrm{F} 2=\frac{P_{i}}{\left(P_{i}\right)_{\max }}$

where,

$P_{i}=$ balue of the incentive for returnable bottle (-), where $1 \leq P_{i} \leq 7$.

$\left(P_{i}\right)_{\max }=$ value of the maximum incentive for returnable bottle $(-)$, where $1 \leq P_{i} \leq 7$.

In general, the monetary incentive assigned at the bottle restitution may vary greatly from country to country or it could depend on the type of bottle's material. It could be also $0 €$, if it is not expected the restitution of a bottle. Consequently, possible incentive's classes were created, corresponding to a low or high benefit, called $P_{i}$ value, in the bottle's restitution. The $P_{i}$ value varies from 1 to 7 . It is assumed that the higher is the incentive, the higher is the $P_{i}$ value and lower is the probability of dispersion. For instance, if the incentive is $0.25 €$, a consumer probably will return the bottle (value $=5$ ). Instead, if the incentive is $0.00 €$, or very low ( $<$ $0.05 €)$, a consumer could not be interested in the bottle restitution, since the income is very low $\left(P_{i}=0\right.$ and $P_{i}=1$, respectively). In this way, it is possible to have a F2's result (different from 0 ), even if the incentive is $0.00 €$ (Table 7).

$F 3=\frac{W_{b}}{\left(W_{b}\right)_{\max }}$

Table 7 Incentives classes and $P_{i}$ value

\begin{tabular}{ll}
\hline Incentives classes & $P_{i}$ value \\
\hline$P=0.00 €$ & 1 \\
$0.00 €<P<0.05 €$ & 2 \\
$0.05 € \leq P<0.15 €$ & 3 \\
$0.15 € \leq P<0.25 €$ & 4 \\
$0.25 € \leq P<0.35 €$ & 5 \\
$0.35 \leq P<0.50 €$ & 6 \\
$P \geq 0.50 €$ & 7 \\
\hline
\end{tabular}

where,

$W_{b}=$ weight of the empty bottle $(\mathrm{kg})$

$\left(W_{b}\right)_{\max }=$ maximum weight of the empty bottles $(\mathrm{kg})$

$F 4=\frac{D_{t}}{\left(D_{t}\right)_{\max }}$

where,

$D_{t}=$ material degradation time (years)

$\left(D_{t}\right)_{\max }=$ maximum time of material degradation (years)

The result of the MLI is therefore an adimensional number: similarly to the work of Civancik-Uslu et al. (Civancik-Uslu, et al., 2019) comparing the MLI results for the four bottle materials considered, it is possible to determine which one is the most impactful, as far as the marine litter is concerned.

\section{Results}

\subsection{Life cycle impact assessment}

Table 8, Table 9, Table 10 and Table 11 show how contribute 11 PET bottle, R-PET bottle, non-returnable and returnable glass bottle to global warming $\left(\mathrm{kg} \mathrm{CO}_{2} \mathrm{eq}\right)$, stratospheric ozone depletion $(\mathrm{kg}$ $\mathrm{CFC}_{11}$ eq), terrestrial acidification ( $\mathrm{kg} \mathrm{SO}_{2}$ eq), fossil resource scarcity ( $\mathrm{kg}$ oil eq), water consumption $\left(\mathrm{m}^{3}\right)$ and human carcinogenic toxicity ( $\mathrm{kg}$ 1.4-DCB). In particular, the contribution of bottle, cap, label, auxiliary materials, transport, packaging phase, distribution and end of life is specified. "Auxiliary materials" refer to secondary and tertiary packaging; "transport" includes the transport of raw materials, while primary and secondary distribution fall in the "distribution" phase. "Packaging phase" consists in blowing, filling and packaging phases for plastic bottles and in sterilization, filling and packaging for glass solutions. Moreover, in Table 11, the reuse scenario for the returnable glass bottles is added considering 8 usages. In order to compare an eight-time reusable bottle to the PET, R-PET and glass bottle used only once, it is supposed that the impact generated by a glass bottle in one single use is the sum of all the abovementioned impacts in its eight uses life cycle, divided by eight.

\subsubsection{Packaging solutions comparison}

Based on the previously reported results, this section aims at comparing the most interesting LCI indicators for the four analysed bottles solutions.

Based on GWP (Fig. 2), a non-returnable glass bottle is the most impactful packaging solution because of its production, packaging phase and distribution phases and its steel cap. In fact, in the glass bottle production, furnaces need high temperature to melt the raw material: silica sand has a melting point of about $1700{ }^{\circ} \mathrm{C}$ and soda is used to reduce melting temperature up to $1500{ }^{\circ} \mathrm{C}$. This involves high consume of energies and greenhouse gases as $\mathrm{CO}_{2}$ and $\mathrm{N}_{2} \mathrm{O}$ are produced 
Table 8 Life cycle impact assessment of PET bottle

\begin{tabular}{|c|c|c|c|c|c|c|c|c|c|c|}
\hline Impact category & Unit & Total & $\begin{array}{l}\text { PET } \\
\text { bottle }\end{array}$ & $\begin{array}{l}\text { HDPE } \\
\text { cap }\end{array}$ & Label & $\begin{array}{l}\text { Auxiliary } \\
\text { materials }\end{array}$ & $\begin{array}{l}\text { Transport of raw } \\
\text { materials }\end{array}$ & $\begin{array}{l}\text { Packaging } \\
\text { phase }\end{array}$ & Distribution & EoL \\
\hline Global warming & $\begin{array}{c}\mathrm{kg} \mathrm{CO} \\
\text { eq }\end{array}$ & $1.86 \mathrm{E}-01$ & $9.13 \mathrm{E}-02$ & 8.38E-03 & $2.08 \mathrm{E}-03$ & $3.77 \mathrm{E}-02$ & 4.98E-03 & $2.21 \mathrm{E}-03$ & 8.24E-03 & $3.13 \mathrm{E}-02$ \\
\hline $\begin{array}{l}\text { Stratospheric ozone } \\
\text { depletion }\end{array}$ & $\begin{array}{l}\mathrm{kg} \\
\quad \mathrm{CF}- \\
\mathrm{C}_{11} \mathrm{eq}\end{array}$ & $6.17 \mathrm{E}-08$ & $2.26 \mathrm{E}-08$ & $1.36 \mathrm{E}-09$ & $1.60 \mathrm{E}-10$ & $2.26 \mathrm{E}-08$ & $2.85 \mathrm{E}-09$ & $1.46 \mathrm{E}-09$ & $6.12 \mathrm{E}-09$ & 4.51E-09 \\
\hline $\begin{array}{l}\text { Terrestrial } \\
\text { acidification }\end{array}$ & $\begin{array}{c}\mathrm{kg} \mathrm{SO}_{2} \\
\text { eq }\end{array}$ & $5.63 \mathrm{E}-04$ & $3.01 \mathrm{E}-04$ & $2.56 \mathrm{E}-05$ & $5.48 \mathrm{E}-06$ & $1.34 \mathrm{E}-04$ & $5.60 \mathrm{E}-05$ & $1.30 \mathrm{E}-05$ & $2.03 \mathrm{E}-05$ & 7.49E-06 \\
\hline $\begin{array}{l}\text { Fossil resource } \\
\text { scarcity }\end{array}$ & $\mathrm{kg}$ oil eq & $7.11 \mathrm{E}-02$ & $4.32 \mathrm{E}-02$ & 5.19E-03 & $1.36 \mathrm{E}-03$ & $1.56 \mathrm{E}-02$ & $1.67 \mathrm{E}-03$ & $6.35 \mathrm{E}-04$ & $2.78 \mathrm{E}-03$ & $6.56 \mathrm{E}-04$ \\
\hline Water consumption & $\mathrm{m}^{3}$ & $1.58 \mathrm{E}-03$ & $1.03 \mathrm{E}-03$ & $7.92 \mathrm{E}-05$ & $3.05 \mathrm{E}-05$ & $3.59 \mathrm{E}-04$ & $1.38 \mathrm{E}-05$ & $3.31 \mathrm{E}-05$ & $1.95 \mathrm{E}-05$ & $1.58 \mathrm{E}-05$ \\
\hline $\begin{array}{l}\text { Human carcinogenic } \\
\text { toxicity }\end{array}$ & $\begin{array}{l}\mathrm{kg} \\
\begin{array}{l}\text { 1.4-D- } \\
\text { CB }\end{array}\end{array}$ & $6.53 \mathrm{E}-03$ & $3.75 \mathrm{E}-03$ & $2.40 \mathrm{E}-04$ & 4.68E-05 & $1.98 \mathrm{E}-03$ & $9.79 \mathrm{E}-05$ & $5.11 \mathrm{E}-05$ & $2.04 \mathrm{E}-04$ & $1.55 \mathrm{E}-04$ \\
\hline
\end{tabular}

during the melting process. Moreover, glass bottles need more primary and secondary packaging materials than PET and RPET bottles. Finally, in the primary and secondary distribution of the final product, the glass bottle is more impactful because trucks carry heavier materials $(0.4 \mathrm{~kg}$ against $0.022 \mathrm{~kg}$ of PET/ R-PET bottle).

However, the single use impact of a returnable glass bottle (considered used eight times) is lower than a nonreturnable one, and this is primarily due to the bottle production and disposal which are divided by the 8 cycles. The influences of the label, cap and distribution are the same, but the contribution of auxiliary materials is lower because the secondary and tertiary packaging of verging glass bottle are considered only once. However, returnable glass bottles have an important additional phase: the "reuse", in fact, impacts significantly because of the washing phase energy consumption and of the greenhouse gases emission during transports to the collection centre and companies.
As regards to PET and R-PET bottles, their phases have similar contribution to GWP, but a significant difference is remarkable in the bottle production phase: R-PET involves saving of virgin material, reducing its impact.

PET and R-PET bottles result the lowest impactful solutions as far as Stratospheric ozone depletion is concerned (Fig. 3): they have more or less the same contribution to this environmental issue, but even here some emissions can be saved in the R-PET bottle production. Instead, the glass bottle has a high ozone depletion potential in its production, auxiliary materials and distribution, because substances as chlorofluorocarbons (CFCs), hydrochlorofluorocarbons (HCFC) and other chemicals with chlorine or bromine groups are produced. Even if some enhancement can be obtained with returnable glass bottle, its reuse scenario emits many ozone-depleting substances (ODSs), which are lead to damage the human health because of the radiation increase on the earth.

As far as the terrestrial acidification is concerned (Fig. 4), the glass bottle production, followed by the packaging phase

Table 9 Life cycle impact assessment of R-PET bottle

\begin{tabular}{|c|c|c|c|c|c|c|c|c|c|c|}
\hline Impact category & Unit & Total & $\begin{array}{l}\text { R-PET } \\
\text { bottle }\end{array}$ & $\begin{array}{l}\text { HDPE } \\
\text { cap }\end{array}$ & Label & $\begin{array}{l}\text { Auxiliary } \\
\text { materials }\end{array}$ & $\begin{array}{l}\text { Transport of raw } \\
\text { materials }\end{array}$ & $\begin{array}{l}\text { Packaging } \\
\text { phase }\end{array}$ & Distribution & EoL \\
\hline Global warming & $\begin{array}{c}\mathrm{kg} \mathrm{CO} \\
\text { eq }\end{array}$ & $1.52 \mathrm{E}-01$ & $5.73 \mathrm{E}-02$ & $8.38 \mathrm{E}-03$ & $2.08 \mathrm{E}-03$ & 3.77E-02 & 4.43E-03 & $2.21 \mathrm{E}-03$ & $8.24 \mathrm{E}-03$ & $3.13 \mathrm{E}-02$ \\
\hline $\begin{array}{l}\text { Stratospheric ozone } \\
\text { depletion }\end{array}$ & $\begin{array}{l}\mathrm{kg} \\
\quad \mathrm{CF}- \\
\mathrm{C}_{11} \text { eq }\end{array}$ & $5.72 \mathrm{E}-08$ & $1.81 \mathrm{E}-08$ & $1.36 \mathrm{E}-09$ & $1.60 \mathrm{E}-10$ & $2.26 \mathrm{E}-08$ & 2.84E-09 & $1.46 \mathrm{E}-09$ & $6.12 \mathrm{E}-09$ & $4.51 \mathrm{E}-09$ \\
\hline $\begin{array}{l}\text { Terrestrial } \\
\text { acidification }\end{array}$ & $\begin{array}{c}\mathrm{kg} \mathrm{SO}_{2} \\
\text { eq }\end{array}$ & 4.27E-04 & $1.88 \mathrm{E}-04$ & $2.56 \mathrm{E}-05$ & $5.48 \mathrm{E}-06$ & $1.34 \mathrm{E}-04$ & $3.30 \mathrm{E}-05$ & $1.30 \mathrm{E}-05$ & 2.03E-05 & 7.49E-06 \\
\hline $\begin{array}{l}\text { Fossil resource } \\
\text { scarcity }\end{array}$ & $\mathrm{kg}$ oil eq & 5.33E-02 & $2.55 \mathrm{E}-02$ & 5.19E-03 & $1.36 \mathrm{E}-03$ & $1.56 \mathrm{E}-02$ & $1.54 \mathrm{E}-03$ & $6.35 \mathrm{E}-04$ & $2.78 \mathrm{E}-03$ & $6.56 \mathrm{E}-04$ \\
\hline Water consumption & $\mathrm{m}^{3}$ & $1.24 \mathrm{E}-03$ & 6.89E-04 & 7.92E-05 & $3.05 \mathrm{E}-05$ & $3.59 \mathrm{E}-04$ & $1.26 \mathrm{E}-05$ & $3.31 \mathrm{E}-05$ & $1.95 \mathrm{E}-05$ & $1.58 \mathrm{E}-05$ \\
\hline $\begin{array}{l}\text { Human carcinogenic } \\
\text { toxicity }\end{array}$ & $\begin{array}{l}\mathrm{kg} \\
\begin{array}{l}\text { 1.4-D- } \\
\text { CB }\end{array}\end{array}$ & $5.23 \mathrm{E}-03$ & $2.47 \mathrm{E}-03$ & $2.40 \mathrm{E}-04$ & $4.68 \mathrm{E}-05$ & $1.98 \mathrm{E}-03$ & $8.40 \mathrm{E}-05$ & $5.11 \mathrm{E}-05$ & 2.04E-04 & $1.55 \mathrm{E}-04$ \\
\hline
\end{tabular}


Table 10 Life cycle impact assessment of non-returnable glass bottle

\begin{tabular}{|c|c|c|c|c|c|c|c|c|c|c|}
\hline Impact category & Unit & Total & $\begin{array}{l}\text { Glass } \\
\text { bottle }\end{array}$ & Steel cap & Label & $\begin{array}{l}\text { Auxiliary } \\
\text { materials }\end{array}$ & $\begin{array}{l}\text { Transport of raw } \\
\text { materials }\end{array}$ & $\begin{array}{l}\text { Packaging } \\
\text { phase }\end{array}$ & Distribution & EoL \\
\hline Global warming & $\begin{array}{l}\mathrm{kg} \mathrm{CO}_{2} \\
\text { eq }\end{array}$ & 4.30E-01 & $2.28 \mathrm{E}-01$ & $1.66 \mathrm{E}-02$ & $2.24 \mathrm{E}-03$ & 8.98E-02 & $1.76 \mathrm{E}-02$ & 9.94E-04 & $4.85 \mathrm{E}-02$ & $2.54 \mathrm{E}-02$ \\
\hline $\begin{array}{l}\text { Stratospheric ozone } \\
\text { depletion }\end{array}$ & $\begin{array}{l}\mathrm{kg} \\
\quad \mathrm{CF}- \\
\quad \mathrm{C}_{11} \text { eq }\end{array}$ & $1.98 \mathrm{E}-07$ & $8.16 \mathrm{E}-08$ & $5.06 \mathrm{E}-09$ & $2.02 \mathrm{E}-10$ & 5.44E-08 & $1.28 \mathrm{E}-08$ & 4.17E-10 & $3.61 \mathrm{E}-08$ & 7.46E-09 \\
\hline $\begin{array}{l}\text { Terrestrial } \\
\quad \text { acidification }\end{array}$ & $\underset{\mathrm{eq}}{\mathrm{kg} \mathrm{SO}}$ & $1.59 \mathrm{E}-03$ & $1.02 \mathrm{E}-03$ & $7.20 \mathrm{E}-05$ & $5.84 \mathrm{E}-06$ & $2.96 \mathrm{E}-04$ & 4.52E-05 & $3.88 \mathrm{E}-06$ & 1.19E-04 & $2.63 \mathrm{E}-05$ \\
\hline $\begin{array}{l}\text { Fossil resource } \\
\text { scarcity }\end{array}$ & $\mathrm{kg}$ oil eq & $1.41 \mathrm{E}-01$ & $6.99 \mathrm{E}-02$ & $3.99 \mathrm{E}-03$ & $1.39 \mathrm{E}-03$ & $3.95 \mathrm{E}-02$ & $6.38 \mathrm{E}-03$ & $2.96 \mathrm{E}-04$ & $1.64 \mathrm{E}-02$ & $3.48 \mathrm{E}-03$ \\
\hline Water consumption & $\mathrm{m}^{3}$ & $3.28 \mathrm{E}-03$ & $1.80 \mathrm{E}-03$ & $9.05 \mathrm{E}-05$ & $2.95 \mathrm{E}-05$ & 8.86E-04 & $5.15 \mathrm{E}-05$ & $2.46 \mathrm{E}-04$ & $1.15 \mathrm{E}-04$ & 4.87E-05 \\
\hline $\begin{array}{l}\text { Human carcinogenic } \\
\text { toxicity }\end{array}$ & $\begin{array}{l}\mathrm{kg} \\
\begin{array}{l}1.4-\mathrm{D}- \\
\mathrm{CB}\end{array}\end{array}$ & $1.69 \mathrm{E}-02$ & $4.68 \mathrm{E}-03$ & $6.37 \mathrm{E}-03$ & 4.93E-05 & $3.95 \mathrm{E}-03$ & $3.17 \mathrm{E}-04$ & $5.51 \mathrm{E}-05$ & $1.20 \mathrm{E}-03$ & $2.69 \mathrm{E}-04$ \\
\hline
\end{tabular}

and by the auxiliary materials, produces a lot of $\mathrm{NO}_{\mathrm{x}}, \mathrm{NH}_{3}$, $\mathrm{SO}_{2}$ that potentially causes a change in acidity in the soil. Once again, the PET and R-PET impacts are lower compared to returnable and non-returnable glass bottles.

The fossil resource scarcity results (Fig. 5) show that the glass production has the higher impact, which is mainly related to the use of non-renewable resources during the bottle production phase. In fact, even if silica sand has not a fossil origin, glass is more impactful than plastics because of the fossil fuels involved in the forming process. Moreover, glass auxiliary materials contribute more to this environmental issue because fewer materials are transported for each journey.

Finally, non-returnable glass bottle highly contributes to water consumption because of the water cooling and the water turbine use to serve the bottle production (Fig. 6). Moreover, also the auxiliary materials and the packaging phase involve a lot of water use due to their production cycles. Instead, PET and R-PET bottles require less water, which is used only for the cooling phase during the injection moulding. Finally, returnable bottle involves a great amount of water in the reuse phase, because it is used to wash the bottles.

Human carcinogenic toxicity has been performed to investigate heavy metals in PET and recycled PET packaging, because recycling process can increase the degradation of the product (Whitt, et al., 2016) and heavy metals as chromium, nickel, lead and cadmium could be released in the product from PET. Processes like heating and microwave can also increase the amount of substances in the products (Cheng, et al., 2010); a study investigated heavy metals concentration in PET packaging for water and the concentration of heavy substances was low (Pehlic, et al., 2018). In this study, human carcinogenic toxicity results (Fig. 7) show that non-returnable glass bottle has the highest impact than the others solutions. This is due to the presence of heavy metals in steel cap, auxiliary materials and bottle production, which are the most impactful phases. As concerned bottles material, glass has a

Table 11 Life cycle impact assessment of returnable glass bottle (8 uses and 7 cycles of return)

\begin{tabular}{|c|c|c|c|c|c|c|c|c|c|c|}
\hline Impact category & Unit & $\begin{array}{l}\text { Glass } \\
\text { bottle }\end{array}$ & Steel cap & Label & $\begin{array}{l}\text { Auxiliary } \\
\text { materials }\end{array}$ & $\begin{array}{l}\text { Transport of raw } \\
\text { materials }\end{array}$ & $\begin{array}{l}\text { Packaging } \\
\text { phase }\end{array}$ & Distribution & EoL & $\begin{array}{l}\text { Reuse } \\
\text { scenario }\end{array}$ \\
\hline Global warming & $\begin{array}{c}\mathrm{kg} \mathrm{CO} \\
\text { eq }\end{array}$ & $2.86 \mathrm{E}-02$ & $1.66 \mathrm{E}-02$ & $2.24 \mathrm{E}-03$ & $5.80 \mathrm{E}-02$ & $4.90 \mathrm{E}-03$ & 9.94E-04 & $4.85 \mathrm{E}-02$ & $8.50 \mathrm{E}-03$ & $3.82 \mathrm{E}-02$ \\
\hline $\begin{array}{l}\text { Stratospheric ozone } \\
\text { depletion }\end{array}$ & $\begin{array}{l}\mathrm{kg} \\
\quad \mathrm{CF}- \\
\mathrm{C}_{11} \text { eq }\end{array}$ & $1.02 \mathrm{E}-08$ & $5.06 \mathrm{E}-09$ & $2.02 \mathrm{E}-10$ & $4.69 \mathrm{E}-08$ & $3.58 \mathrm{E}-09$ & 4.17E-10 & $3.61 \mathrm{E}-08$ & $2.09 \mathrm{E}-09$ & $2.71 \mathrm{E}-08$ \\
\hline $\begin{array}{l}\text { Terrestrial } \\
\text { acidification }\end{array}$ & $\underset{\mathrm{eq}}{\mathrm{kg} \mathrm{\textrm {SO } _ { 2 }}}$ & $1.28 \mathrm{E}-04$ & $7.20 \mathrm{E}-05$ & $5.84 \mathrm{E}-06$ & $2.00 \mathrm{E}-04$ & $1.26 \mathrm{E}-05$ & $3.88 \mathrm{E}-06$ & $1.19 \mathrm{E}-04$ & $6.99 \mathrm{E}-06$ & $1.04 \mathrm{E}-04$ \\
\hline $\begin{array}{l}\text { Fossil resource } \\
\text { scarcity }\end{array}$ & $\mathrm{kg}$ oil eq & $8.74 \mathrm{E}-03$ & $3.99 \mathrm{E}-03$ & $1.39 \mathrm{E}-03$ & $2.16 \mathrm{E}-02$ & $1.78 \mathrm{E}-03$ & $2.96 \mathrm{E}-04$ & $1.64 \mathrm{E}-02$ & $9.00 \mathrm{E}-04$ & $1.26 \mathrm{E}-02$ \\
\hline Water consumption & $\mathrm{m}^{3}$ & $2.25 \mathrm{E}-04$ & $9.05 \mathrm{E}-05$ & $2.95 \mathrm{E}-05$ & $4.65 \mathrm{E}-04$ & $1.44 \mathrm{E}-05$ & $2.46 \mathrm{E}-04$ & $1.15 \mathrm{E}-04$ & $1.43 \mathrm{E}-05$ & 3.67E-04 \\
\hline $\begin{array}{l}\text { Human } \\
\text { carcinogenic } \\
\text { toxicity }\end{array}$ & $\begin{array}{l}\mathrm{kg} \\
\begin{array}{l}1.4-\mathrm{D}- \\
\mathrm{CB}\end{array}\end{array}$ & $5.85 \mathrm{E}-04$ & $6.37 \mathrm{E}-03$ & $4.93 \mathrm{E}-05$ & $2.73 \mathrm{E}-03$ & $8.84 \mathrm{E}-05$ & $5.51 \mathrm{E}-05$ & $1.20 \mathrm{E}-03$ & $7.75 \mathrm{E}-05$ & $9.47 \mathrm{E}-04$ \\
\hline
\end{tabular}


Fig. 2 Global warming of different packaging solutions stages

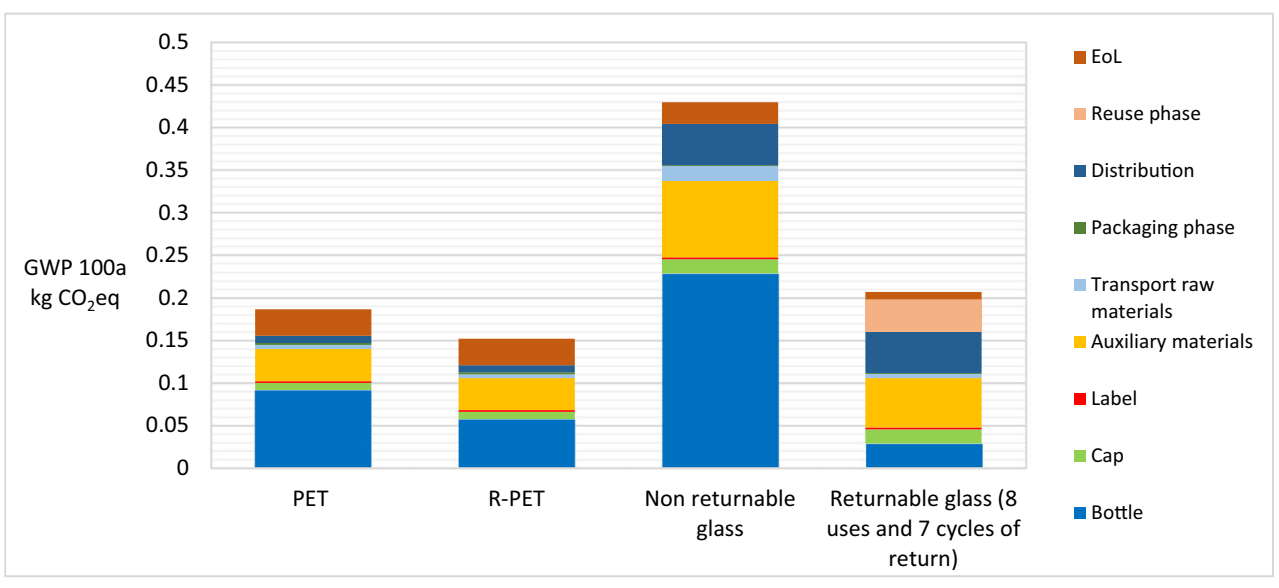

lower human carcinogenic toxicity than PET and R-PET if we consider the same weight, but in this case glass bottle is $0.4 \mathrm{~kg}$ and plastic bottles $22 \mathrm{~g}$. Returnable glass bottle presents a lower impact for bottle production considering 8 uses, because the impact of bottle production is divided into 8 times. Moreover, R-PET bottle is the solution with the lowest impact on human carcinogenic toxicity.

Results of LCA, according to the selected impact categories, demonstrate that R-PET bottle contributes less to global warming, stratospheric ozone depletion, terrestrial acidification, fossil resource scarcity, water consumption and human carcinogenic toxicity than PET bottle, while non-returnable glass bottle give a higher contribution to the considered environmental problems than polymeric bottles. In fact, it should be noted that the current EC regulation related to recycled plastic materials and articles intended to come into contact with food defines that " The converter of recycled plastic material and articles should declare that he is using only recycled plastic from an authorised process and that the final product respects Community and national provisions applicable to it, in particular Regulation (EC) No 1935/2004 and
Directive 2002/72/EC", the last one now replaced by EU REG. 10/2011 (Commission Regulation (EC) No 282/2008, 2008). The finished recycled plastic materials should be accompanied by a declaration of compliance: there is no danger of heavy metals, since processes are controlled and validated. Instead, non-returnable glass results as the worst material option, because of its production, cap, auxiliary materials and finally its distribution phase. Improvements can be obtained as far as returnable glass bottles are concerned, in particular acting on the reuse scenario and cap choice: returnable bottle permits already an energy saving because, in 8 usage cycles, the environmental impact of the production phase is avoided 7 times. If the reuse phase and cap production will be optimized, they could become a sustainable option if compare with polymeric bottles.

\subsection{Marine litter results}

The same quantity of bottles would be required if PET, R-PET or non-returnable glass bottles were used to pack the annual
Fig. 3 Stratospheric ozone depletion for each stage

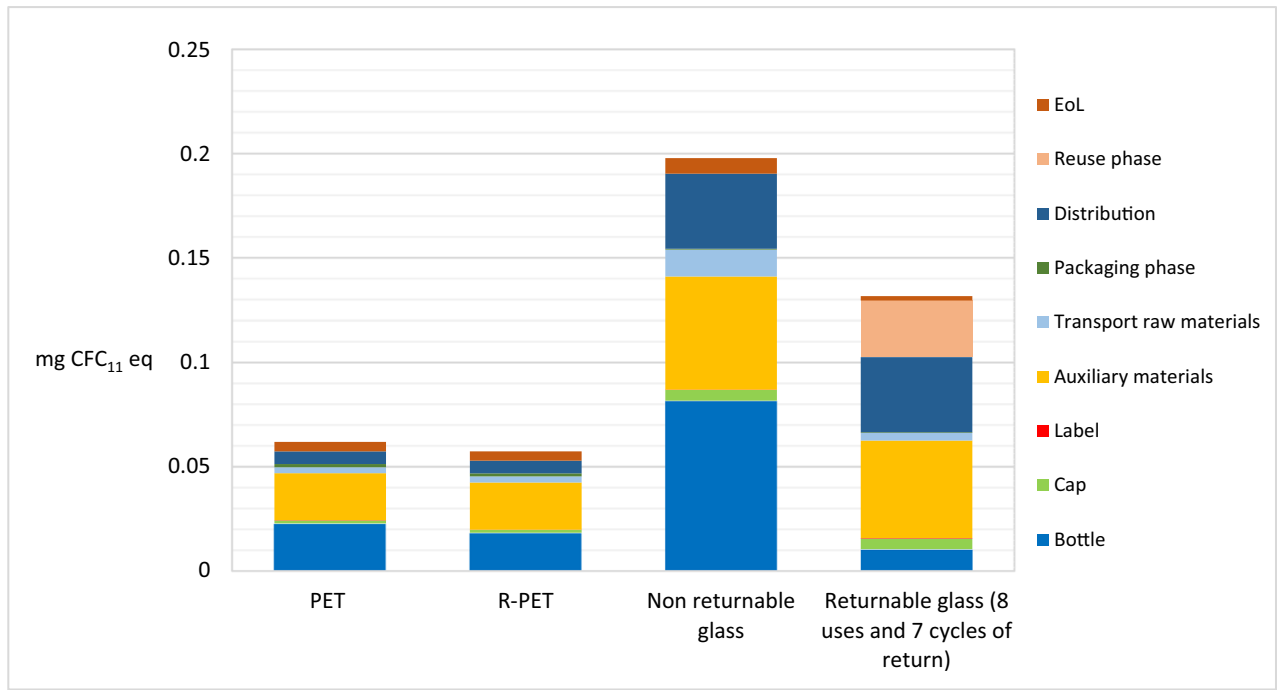


Fig. 4 Terrestrial acidification for each stage

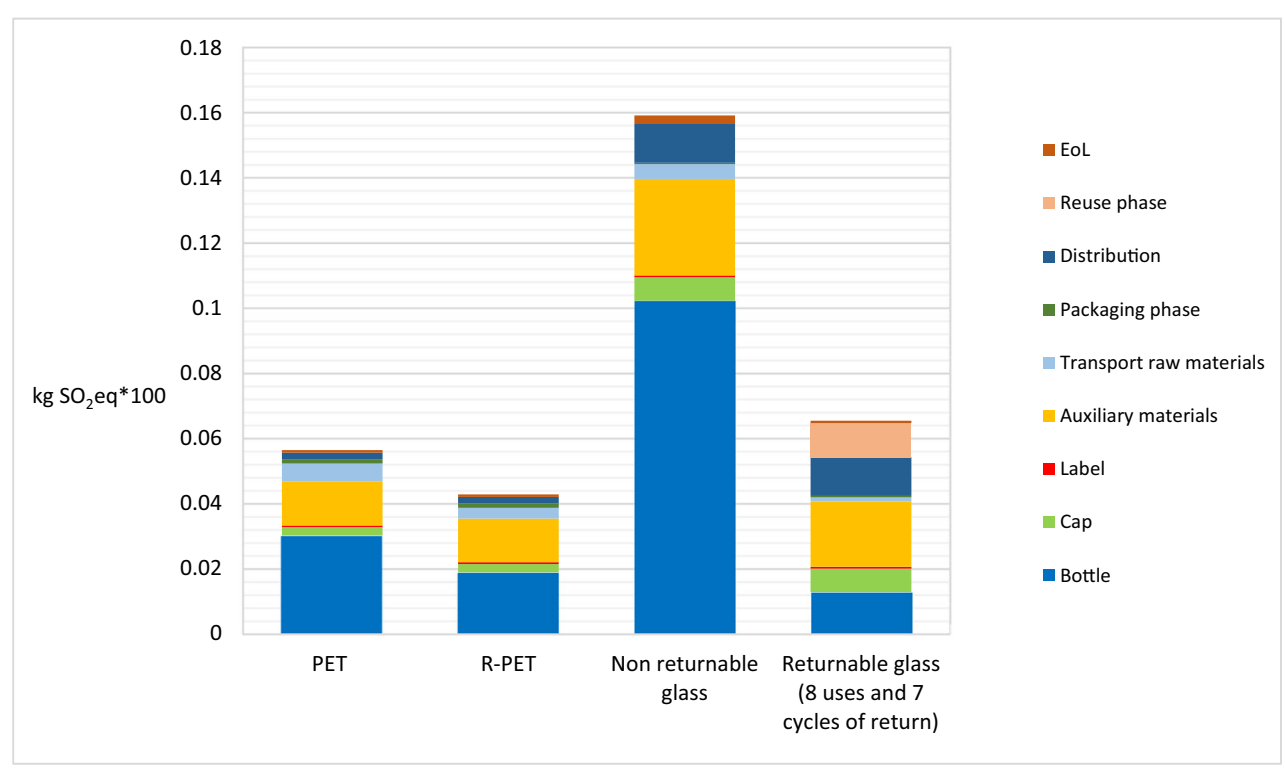

pasteurized milk production in Italy (CLAL, 2018). Thanks to primary data provided by the bottle washer company R.BARDI, it is known that a returnable glass bottle has a cycle of 2 months: it is thus considered that a bottle could be used 6 times in a year before being disposed (R.BARDI, 2020). Therefore, the number of returnable glass bottles need to pack the annual pasteurized milk production is lower than the other bottle types. However, considering that at the end of each cycle, $10 \%$ of bottles need to be replaced because they are dispersed (Il Sole 24 ore, 2017), the "number of real bottles needed" is calculated (Table 12). Then, considering also the Italian dispersion percentages of $11.5 \%$ for non-returnable glass (COREVE, 2019) and $11 \%$ for plastic (COREPLA, 2018), $B_{d}$ parameter is calculated for each packaging material. Results show that a large number of PET and R-PET bottles could be potentially dispersed, followed by disposable glass bottles and finally by a smaller number of returnable glass bottles. Returnable glass bottle, PET and R-PET bottles would guarantee an incentive of 0.25 euros $\left(P_{i}=5\right)$ and 0.05 euros $\left(P_{i}=3\right)$ respectively for each returned bottle, thus limiting the incorrect disposal of these bottles and reducing the MLI. Taking into account real industrial data, PET and R-PET bottles weight is the same $(0.022 \mathrm{~kg})$, while the returnable and non-returnable glass bottles are heavier $(0.40 \mathrm{~kg})$; therefore, even if they are dispersed on the beaches, they are difficult to be dragged into the sea by the wind or waves. Finally, glass bottles take more years than plastic bottles to degrade, thus affecting MLI.

In conclusion, the MLI (Table 12) demonstrates that if nonreturnable glass bottles were dispersed in the environment, they would have much more impact on MLI than PET, RPET and returnable glass bottles. According to the MLI proposed, the best solution would be using returnable glass bottles, thanks to the low number of bottles needed and therefore dispersed, their weight and return incentives. However, it is important to remember that the environmental dispersion of
Fig. 5 Fossil resource scarcity for each stage of different packaging solutions

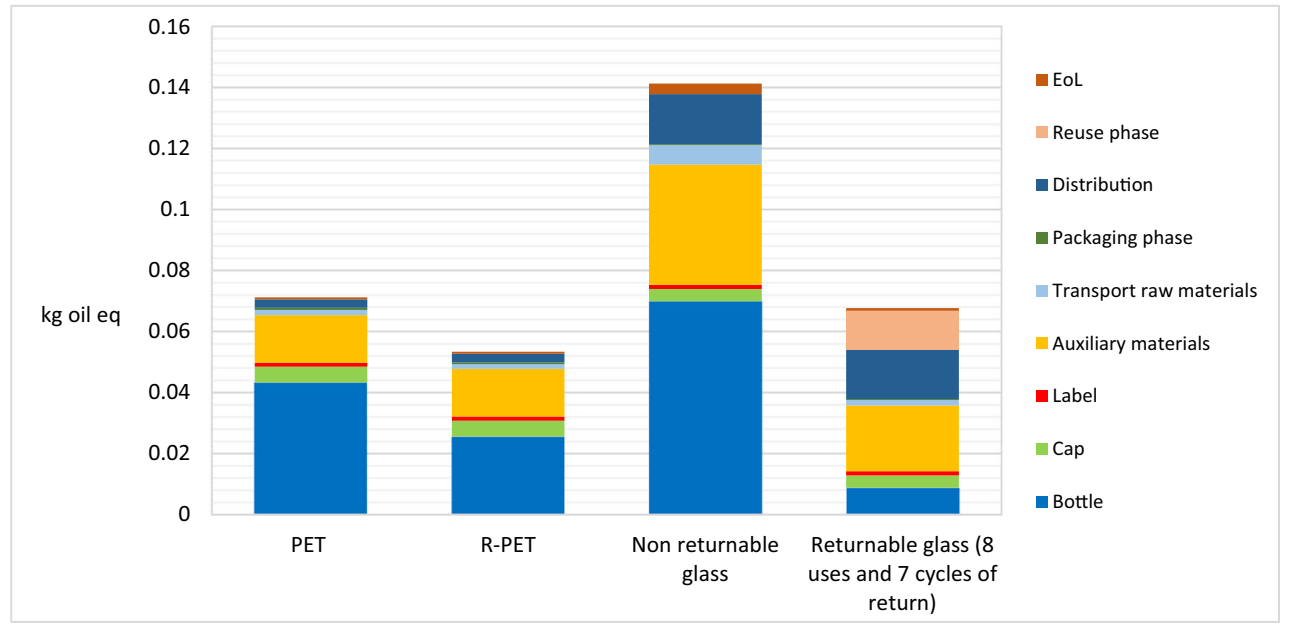


Fig. 6 Water consumption for each stage of different packaging solutions

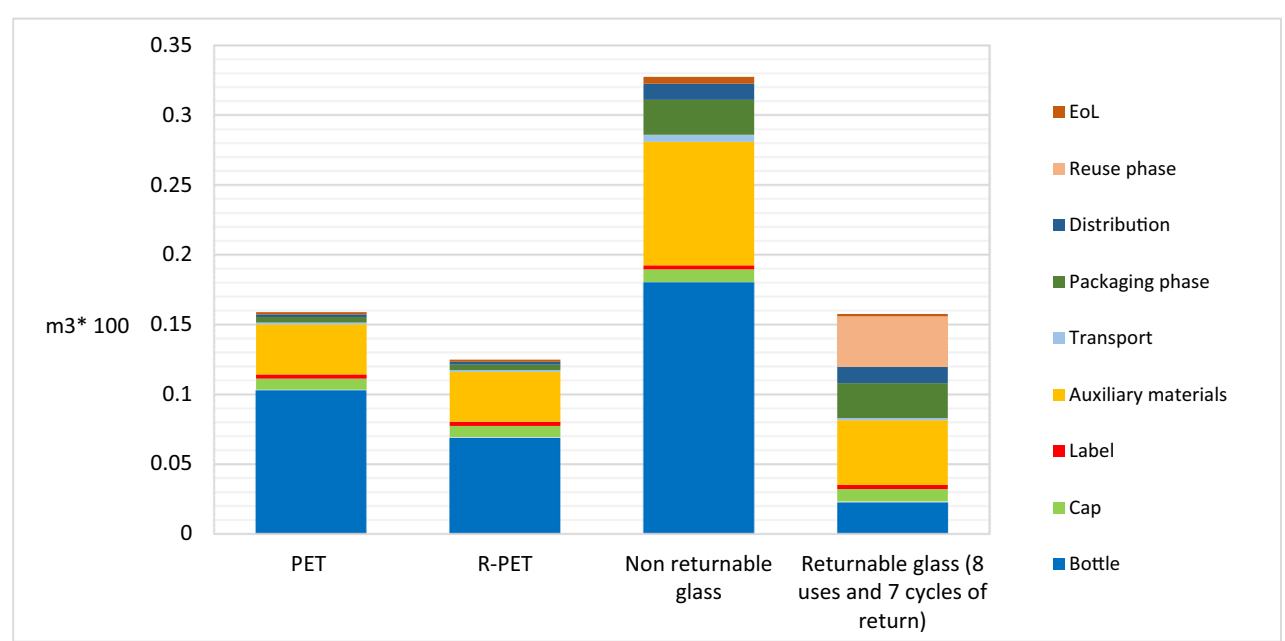

bottle is strictly related to human's behaviour: consequently, it is important to raise the consumers' awareness on this topic.

\subsubsection{Sensitivity analysis}

In the calculation of the MLI, it is assumed that all the factors are equally important; however, some considerations can be made. First of all, the majority of waste is poured into the environment voluntarily (WWF, 2019): the F3 factor, which considers the involuntary dispersion due to the wind or waves, could have a lower weight in the MLI calculation. Secondly, it is expected that the quantity of bottle which could potentially be wasted into the seas is relevant in the MLI. In particular, higher is the number of bottles created to contain a drink product (e.g. the pasteurized milk produced in a year), higher is the quantity that can be dispersed. Therefore, F1 results as the most important factor in the MLI.

However, even if the production of the bottle is high, it is possible to prevent the abandonment using incentives for the bottle restitution at some collecting points. Thus, the F2 factor has a high weight in the MLI calculation. Finally, F4, which is the degradation of the material, depends on many processes (Min et al. 2020): although the decomposition time is relevant for the MLI, the main cause of marine litter is not related to the fast or low decomposition, but to the problem of incorrect waste disposal that is poured into the sea. Consequently, this factor has a higher value than F3, but is less important than F1 and F2. These considerations are supported by Australian research (Willis, et al., 2018): the best ways to reduce the waste along the coastlines are litter prevention, recycling and education programs, which aim to reduce the quantity of plastic production and use, before it is likely to enter the environment. After these reflections, it is possible to attribute different weights - e.g. from 1 to 3 - to the four factors F1, F2, F3 and F4. However, the results do not change: the non-returnable glass is always the most impactful solution (Table 13).

\section{Discussion}

The LCA results obtained agree with those found from the literature analysis: the most impactful phase of the bottle life
Fig. 7 Human carcinogenic toxicity for each stage of different packaging solutions

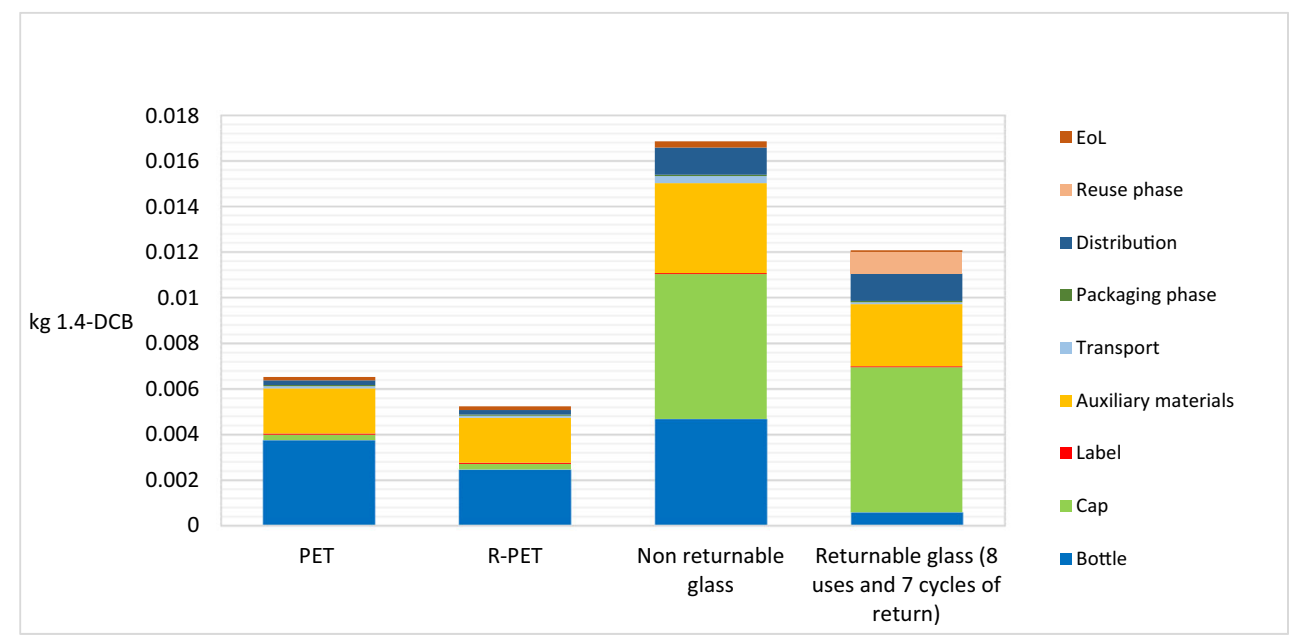


Table 12 Marine litter indicator (MLI) calculation

\begin{tabular}{|c|c|c|c|c|}
\hline Description & PET & R-PET & Non-returnable glass & Returnable glass \\
\hline Italian production of pasteurized milk in a year (ton) & $1,066,860$ & $1,066,860$ & $1,066,860$ & $1,066,860$ \\
\hline Weight of $1 \mathrm{~L}$ milk (ton) & 0.001035 & 0.001035 & 0.001035 & 0.001035 \\
\hline Number of 1 L bottles needed (bottles) & $1,030,782,608.7$ & $1,030,782,608.7$ & $1,030,782,608.7$ & $1,030,782,608.7$ \\
\hline Number of uses in a year (cycle) & 1 & 1 & 1 & 6 \\
\hline$\%$ of dispersed waste in Italy & 0.125 & 0.125 & 0.115 & 0.1 \\
\hline Number of real bottles needed & $1,030,782,608.7$ & $1,030,782,608.7$ & $1,030,782,608.7$ & $274,875,362.32$ \\
\hline$B_{d}$ (bottles) & $128,847,826.09$ & $128,847,826.09$ & $118,540,000$ & $103,078,260.87$ \\
\hline $\mathrm{F} 1=B_{d} / B_{d} \max$ & 1 & 1 & 0.92 & 0.80 \\
\hline$P_{i}(-)$ & 3 & 3 & 1 & 5 \\
\hline $\mathrm{F} 2=P_{i} / P_{i} \max$ & 0.60 & 0.60 & 0.20 & 1 \\
\hline$W_{b}(\mathrm{~kg})$ & 0.02 & 0.02 & 0.40 & 0.40 \\
\hline $\mathrm{F} 3=W_{b} / W_{b} \max$ & 0.05 & 0.05 & 1 & 1 \\
\hline$D_{t}$ (years) & 400 & 400 & 4000 & 4000 \\
\hline $\mathrm{F} 4=D_{t} / D_{t} \max$ & 0.10 & 0.10 & 1 & 1 \\
\hline $\mathrm{MLI}=(\mathrm{F} 1 * \mathrm{~F} 4) /(\mathrm{F} 2 * \mathrm{~F} 3)$ & 3.33 & 3.33 & 4.60 & 0.80 \\
\hline
\end{tabular}

The entries italics is used to underline the "value of each parameter of the Marine Litter Indicator"

cycle is the production of the primary packaging, regardless its material. Furthermore, comparing the different options of packaging materials (PET, R-PET, non-returnable and returnable glass bottle), it is evident that glass bottles have the highest impact on environment, because of their production and transports. In fact, to create a glass bottle a lot of energy is used to reach high temperature. Moreover, plastics can be transported in octabins before the bottle formation in the food companies, while glass bottles are already transported in their final form, that takes up a lot of places and less bottles can be carried at each journey. Finally, glass bottle's weight is very high, and trucks consume more, emitting more pollutants. For these reasons, glass bottle appears as the most impactful material according to global warming, stratospheric ozone depletion, terrestrial acidification, fossil resource scarcity and water consumption. In order to illustrate all the impact categories, results in the chart a normalization process has been done considering the highest score for each indicator as shown in Fig. 8. The chart illustrates the percentage differences between the contributions of each bottle to a specific category impact.
Results show that returnable glass permits saving of emissions in comparison to non-returnable glass bottle, but is important to understand which the contribution of each use cycle is. Figure 9 evaluates the cycle's impact on the global warming in multiple uses of a glass bottle. If we consider only a single use, GWP is obviously equal to the non-returnable glass bottle life cycle: it supposed that a glass bottle is produced, used and then disposed. If we consider two uses, the bottle is produced once, but used twice: its impact is due to the production of the bottle and then the washing, transport, filling, new cap and label, distribution, and finally the bottle disposal at the end of the second cycle. Therefore, the environmental impact of this bottle is the sum of impact of the 2 cycles divided by two. The same is assumed for the other number of uses up to the eighth, which considers seven reuses after the first production of the bottle. The final bottle impact is equal to the sum of impacts attributable to one production and a final disposal and seven washings, transports, auxiliary materials and distribution. In order to obtain the impact of this packaging solution, the total impact of the 8 uses is divided by
Table 13 MLI calculation considering weighting factors

\begin{tabular}{|c|c|c|c|c|}
\hline MLI calculation & PET & $\begin{array}{l}\text { R- } \\
\text { PET }\end{array}$ & Non-returnable glass & Returnable glass \\
\hline $\mathrm{MLI}=\left(\mathrm{F} 1^{\wedge} 3^{*} \mathrm{~F} 4^{\wedge} 2\right) /\left(\mathrm{F} 2^{\wedge} 2^{*} \mathrm{~F} 3^{\wedge} 1\right)$ & 0.56 & 0.56 & 19.47 & 0.78 \\
\hline $\mathrm{MLI}=\left(\mathrm{F} 1^{\wedge} 2^{*} \mathrm{~F} 4^{\wedge} 1\right) /\left(\mathrm{F} 2^{\wedge} 2^{*} \mathrm{~F} 3^{\wedge} 1\right)$ & 5.56 & 5.56 & 21.16 & 0.85 \\
\hline $\mathrm{MLI}=\left(\mathrm{F} 1^{\wedge} 1^{*} \mathrm{~F} 4^{\wedge} 1\right) /\left(\mathrm{F} 2^{\wedge} 1^{*} \mathrm{~F} 3^{\wedge} 0.5\right)$ & 0.75 & 0.75 & 4.60 & 0.92 \\
\hline $\mathrm{MLI}=\left(\mathrm{F} 1^{\wedge} 2^{*} * \mathrm{~F} 4^{\wedge} 1\right) /\left(\mathrm{F} 2^{\wedge} 2^{*} * \mathrm{~F} 3^{\wedge} 0.5\right)$ & 1.24 & 1.24 & 21.16 & 0.85 \\
\hline $\mathrm{MLI}=\left(\mathrm{F} 11^{\wedge} 2^{*} \mathrm{~F} 4^{\wedge} 2\right) /\left(\mathrm{F} 2^{\wedge} 3^{*} \mathrm{~F} 3^{\wedge} 1\right)$ & 0.93 & 0.93 & 105.80 & 0.85 \\
\hline
\end{tabular}


Fig. 8 Indicators results of each bottle material

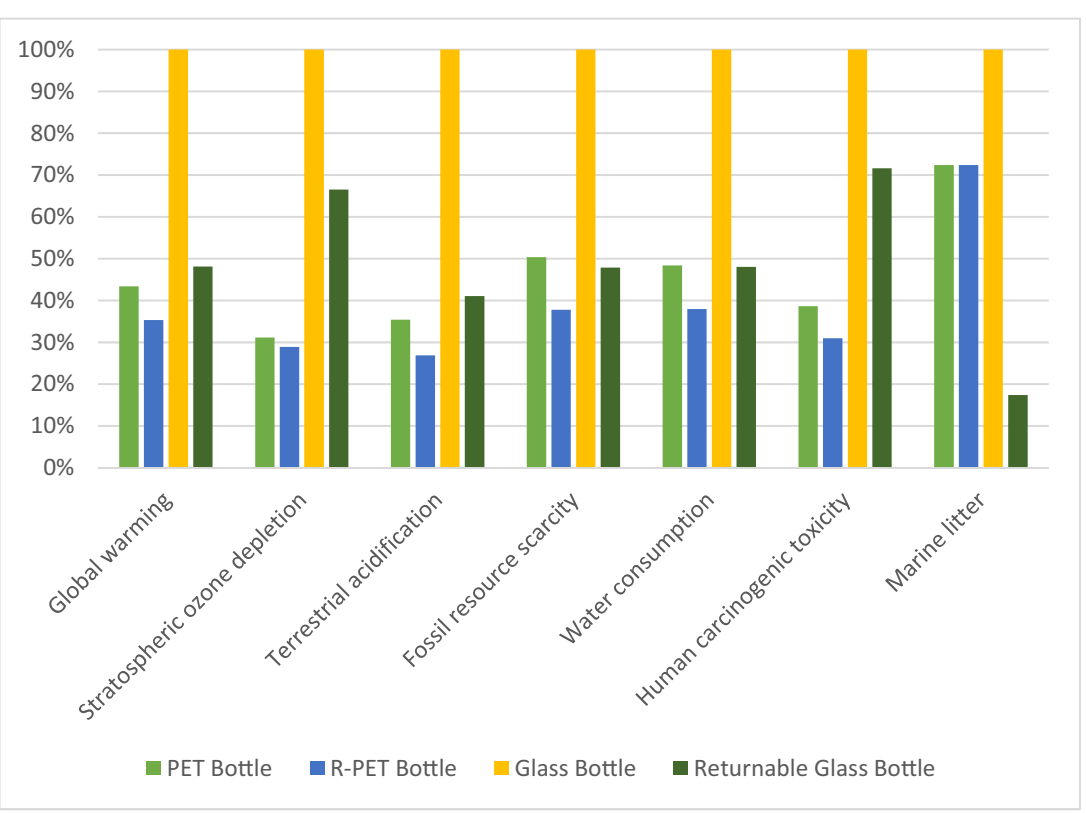

the eight. The obtained results confirm what is found for 0.75 glass bottles in the work located in UK about the soft drinks (Amienyo, et al., 2013). The contribution to GWP diminishes every cycle thanks to the saving of emissions due to the production phase that is avoided thanks to the reuse. However, the savings percentage decreases with the uses: primary, secondary and tertiary packaging production and disposal, followed by primary and secondary distribution and washing phases of each reuse cycles, are very impactful. Consequently, augmenting the number of reuse, the cycle's impact asymptotically tends to the impact of the washing and distribution phase that characterised the reuse scenario. According to primary data provided by R.Bardi (R.BARDI, 2020), in some countries of Europe, a returnable glass bottle can do 30 cycles. Therefore, assuming that a glass bottle could be used 30 times before its EoL, the contribution to GWP of this reusable bottle is quite similar to a PET bottle used once. The same hypothesis has been made for the other impacts categories and the results show that, considering a 30 times reused glass bottle, its cycle's contribution to stratospheric ozone depletion and human carcinogenic toxicity is higher than the contribution of a PET bottle. A glass bottle has to be used about 7 times to compare its contribution to fossil resource scarcity and water consumption to a PET bottle and about 27 times to compare its contribution to terrestrial acidification. Furthermore, neither with 30 reuse cycles, a returnable glass bottle has lower impact than recycled PET bottle. Consequently, these LCA results do not support the substitution of plastic with glass.

However, considering the MLI, results are different. In order to contain the annual production of pasteurized milk, many PET or R-PET bottles are necessary and the potential number of dispersed bottles is high. There is no difference between the marine litter of PET and R-PET: their disposal into the environment has the same effects, because their weight and their biodegradability are the same. Instead, assuming that the annual production of milk is packaged in glass bottles, the number of potential bottles dispersed is lower, because according to the Italian annual report (COREVE, 2019), also its dispersion is lower. Moreover, considering returnable glass bottles, the number of used bottles is limited and their dispersion is disadvantaged thanks to the return incentives. Some assumptions have been done to elaborate the proposed MLI: other parameters could be considered, for example the influence of tourism on the waste dispersion, or the

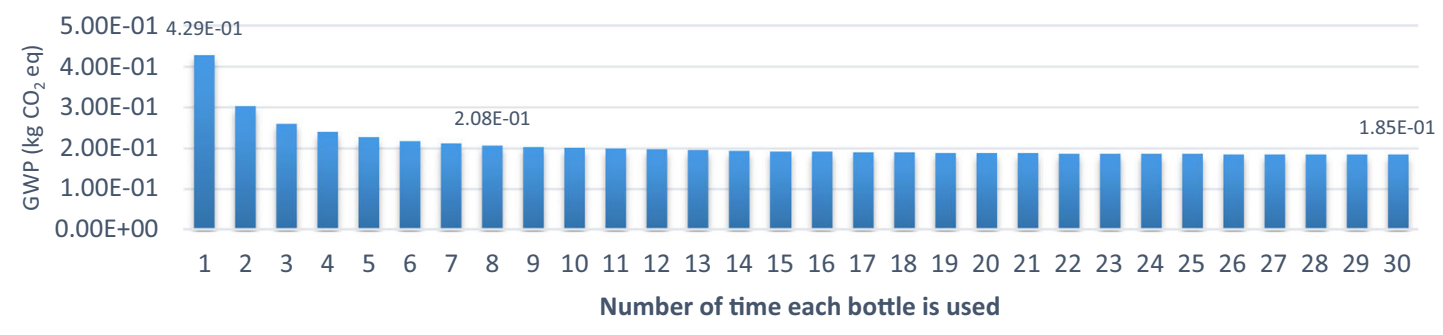

Fig. 9 Contribution to global warming of each use cycle of a returnable glass bottle 
frequency of tides that collect litter on the beaches, polluting the sea. Moreover, it is very difficult to consider in a mathematical expression the single human behaviour, which disposes incorrectly its waste, and is responsible for the marine litter.

\section{Conclusions}

In the last years, incorrect plastic disposal has led to marine litter, which is causing many environmental problems to the maritime flora and fauna all over the world. Someone thinks that the solution to solve it and overall to reduce the environmental impact of the food packaging is the abolition of plastic and its substitution with glass or other materials, but few studies aimed at scientifically demonstrate it. In order to give a contribution to this issue, this study compared four packaging solutions able to contain 11 of pasteurized milk: a PET bottle, an R-PET bottle, a non-reusable and a reusable glass bottle. The final goal was to assess what is the lowest impactful solution for the environment, thanks to the application of the LCA methodology, considering the global warming potential, stratospheric ozone depletion, terrestrial acidification, fossil resource scarcity, water consumption and human carcinogenic toxicity impact categories. Moreover, in order to evaluate the impact of potential dispersion into the sea, a marine litter indicator was proposed.

Results show that R-PET bottle has the lowest impact for all the selected LCA categories, followed by PET bottle, returnable glass bottle with 8 use cycles, and finally nonreturnable bottle. This is due to the savings of virgin materials, its low weight and its lower energy consumption in the production phase and transports. The most impactful solution is the non-returnable glass bottle, while better results are obtained using returnable glass bottles: using many times the same bottle, there is only a production and disposal phase, then the majority of the impacts are connected to the cap, label and washing and transport phase. However, even considering 30 use cycles before the glass bottle disposal, its impact is not comparable to the R-PET bottle. Perhaps, reducing the glass bottle weight as much as possible and modifying the cap, its environmental impact could be reduced, but there are still some researches to do for ensuring a bottle shock resistance. According to the MLI proposed, non-returnable glass bottles are the worst material option, followed by PET, R-PET and finally returnable glass bottles. As far as this indicator is concerned, investing on glass bottles reuse and augmenting the incentives of the bottle restitution will help to reduce the marine litter. Furthermore, from a methodological point of view, possible changes could be made to this indicator, such as the adding of other factors or the use of specific weight for each parameter, as already expected but not applied in this study.
In conclusion, according to the study's considerations and results, it emerges also that raising the people awareness of environmental problems, investing in plastic recycling and recycled plastic as R-PET, could reduce seas and oceans pollutions and limit the maritime flora and fauna damages.

Acknowledgements Open access funding provided by Universita degli Studi di Parma within the CRUI-CARE Agreement. The authors wish to thank Parmalat S.p.A. for providing data used in the inventory analysis.

Open Access This article is licensed under a Creative Commons Attribution 4.0 International License, which permits use, sharing, adaptation, distribution and reproduction in any medium or format, as long as you give appropriate credit to the original author(s) and the source, provide a link to the Creative Commons licence, and indicate if changes were made. The images or other third party material in this article are included in the article's Creative Commons licence, unless indicated otherwise in a credit line to the material. If material is not included in the article's Creative Commons licence and your intended use is not permitted by statutory regulation or exceeds the permitted use, you will need to obtain permission directly from the copyright holder. To view a copy of this licence, visit http://creativecommons.org/licenses/by/4.0/.

\section{References}

Amienyo D, Guiba H, Stichnothe H, Azapagic A (2013) Life cycle environmental impacts of carbonated soft drink. Int J Life Cycle Assess 18(1):77-92

Bertolini M, Bottani E, Vignali G, Volpi A (2016) Comparative life cycle assessment of packaging systems for extended shelf life milk. Packag Technol Sci 29:525-546

Bertoluzzi, A., 2019. EPD. [Online] Available at: https://www. environdec.com/PCR/Detail/?Pcr=13818

Boesen S, Bey N, Niero M (2019) Environmental sustainability of liquid food packaging: Is there a gap between Danish consumers' perception and learnings from life cycle assessment? J Clean Prod 210: $1193-1206$

Cheng X, Shi H, Adams CD, Ma Y (2010) Assessment of metal contaminations leaching out from recycling plastic bottles upon treatments. Environ Sci Pollut Res 17:1323-1330

Civancik-Uslu D, Puig R, Hauschild M, Fullana-i-Palmer P (2019) Life cycle assessment of carrier bags and development of a littering indicator. Sci Total Environ 685:621-630

CLAL, 2018. Clal.it. [Online] Available at: https://www.clal.it/index. php?section=bilancio_approv2\&year $=2018$

COMIECO, 2019. Consorzio Nazionale Recupero e Riciclo degli Imballaggi a base Cellulosica. [Online] Available at: https:// www.comieco.org/allegati/2019/8/24mo-rapporto-comieco_datianno-2018_179877.pdf

CONAI, 2019. Consorzio Nazionale Imballaggi. [Online] Available at: http://www.conai.org/comunicazione/rapporto-di-sostenibilitapage/

COREPLA, 2018. Il Consorzio nazionale per la raccolta, il riciclaggio e il recupero degli imballaggi in plastica. [Online] Available at: http:// www.corepla.it/documenti/7ebe 111 b-2082-46d5-8da67567154632ca/Rapporto+di+Sostenibilita\%CC\%80+2018.pdf

COREVE, 2019. Consorzio per il riciclo del vetro. [Online] Available at: https://coreve.it/wp-content/uploads/2019/06/ PspCorevemaggio2019-dati2018-31maggio2019.pdf

CORIPET, 2020. [Online] Available at: https://coripet.it/[Accessed 2020]. 
Dhaliwal H, Browne M, Flanagan W, Laurin L, Hamilton M (2014) A life cycle assessment of packaging options for contrast media delivery: comparing polymer bottle vs. glass bottle. Int J Life Cycle Assess 19:1965-1973

Djekic L, Miocinovic J, Tomasevic J, Smigic N, Tomic N (2014) Environmental life-cycle assessment of various dairy products. J Clean Prod 68:64-72

European Commission, 2003. Communication on Integrated Product Policy (COM 302), s.l.: s.n.

Il ministro dell'ambiente, 2017. Gazzetta ufficiale della Repubblica Italiana. [Online] Available at: https://www.gazzettaufficiale.it/eli/ $\mathrm{id} / 2017 / 09 / 25 / 17 \mathrm{G} 00154 / \mathrm{sg}$ [Accessed 2020].

Il Sole 24 ore, 2017. Torna il "vuoto a rendere": al via la sperimentazione di un anno. [Online] Available at: https://www.ilsole24ore.com/art/ torna-vuoto-rendere-via-sperimentazione-un-anno-AENKyuZC [Accessed 2020].

Jungbluth N, Keller R, Meili C (2018) Life cycle assessment of a detailed dairy processing model and recommendations for the allocation to single products. Int J Life Cycle Assess 23(1806-1813)

Laca A, Gómez N, Laca A, Díaz M (2020) Overview on GHG emissions of raw milk production and a comparison of milk and cheese carbon footprints of two different systems from northern Spain. Environ Sci Pollut R 27:1650-1666

Landi D, Germani M, Marconi M (2019) AnalysingAnalyzing the environmental sustainability of glass bottles reuse in an italian wine consortium. Proc CIRP 80:399-404

Lauretana, 2020. [Online] Available at: https://www.lauretana.com/en/ [Accessed 2020].

Legambiente, 2019. [Online] Available at: https://www.legambiente.it/ wp-content/uploads/dossier_beachlitter2019.pdf

Liubartseva S, Coppini G, Lecci R, Clementi E (2018) Tracking plastics in the Mediterranean: 2D Lagrangian model. Mar Pollut Bull 129: $151-162$

Makesense, 2018. How to tackle beverage waste in tourism and events? [Online] Available at: https://futureofwaste.makesense.org/beverage-waste/ [Accessed 205 2,020].

Manfredi M, Fantin V, Vignali G, Gavara R (2015) Environmental assessment of antimicrobial coatings for packaged fresh milk. J Clean Prod 95:291-300

Mata T, Costa C (2001) Life cycle assessment of different reuse percentages for glass beer bottles. Int J Life Cycle Assess 6(5):307-319

Meneses M, Pasqualino J, Castells F (2012) Environmental assessment of the milk life cycle: tThe effect of packaging selection. J Environ Manag 107:76-83

Min K, Cuiffi J, Mathers R (2020) Ranking environmental degradation trends of plastic marine debris based on physical properties and molecular structure. Nat Commun 11(1):art. no. 727

Nutter WD, Dae-Soo K, Ulrich R, Thoma G (2013) Greenhouse gas emission analysis for USA fluid milk processing plants: processing. packaging and distribution Int Dairy J 31:S57-S64

Pasqualino J, Meneses M, Castells F (2011) The carbon foot print and energy consumption of beverage packaging selection and disposal. J Food Eng 103(4):357-365
Pehlic E, Sapcanin A, Nanic H, Ceajic A (2018) The content of heavy metals in PET bottles of drinking water and its electrical conductivity. NEW TECHNOLOGIES NT, Sarajevo, Bosnia and Herzegovina

Plastic Europe, 2019. Plastics - The facts 2019. [Online] Available at: https://www.plasticseurope.org/it/resources/publications/1804plastics-facts-2019

R.BARDI, 2020. [Online] Available at: https://www.r-bardi.com/index. php [Accessed 2020].

Ragaert, K., 2019. TEDx. [Online] Available at: https://www.youtube. $\mathrm{com} /$ watch? $\mathrm{v}=11 \mathrm{BaOlEJ}$ eE\&trk=public-post_share-video-embed share-article title

RICREA, 2020. Raccolta e Riciclo Imballaggi Acciaio. [Online] Available at: https:/www.consorzioricrea.org/wp-content/uploads/ 2020/01/Dichiarazione-Ambientale-RICREA-2019.pdf

RILEGNO, 2019. Consorzio nazionale per la raccolta, il recupero e il riciclaggio degli imballaggi in legno. [Online] Available at: http:// www.rilegno.org/wp-content/uploads/2019/05/Rilegno.Rapporto. 2019.sito_.pdf

Robertson, G., 2012. Food Packaging, Principle and Practice. Third edition ed. s.1.:CRC Press.

Saleh Y (2015) Comparative life cycle assessment of beverages packages in Palestine. J Clean Prod 131:28-42

Strazza C, Del Borghi A, Magrassi F, Gallo M (2016) Using the environmental product declaration as source of data for life cycle assessment: a case study. J Clean Prod 112:333-342

Thoma G, Popp J, Nutted D, Shonnard D, Ulrich R, Matlock M, Kim DS, Neiderman Z, Kemper N, East C, Felix Adomd F (2013) Greenhouse gas emissions from milk production and consumption in the United States: a cradle-to-grave life cycle assessment circa 2008. Int Dairy J 31:S3-S14

Vitale G, Mosna D, Bottani E, Montanari R, Vignali G (2018) Environmental impact of a new industrial process for the recovery and valorisation of packaging materials derived from packaged food waste. Sust Prod Consump 14:105-121

Whitt M, Brown W, Danes JE, Vorst KL (2016) Migration of heavy metals from recycled polyethylene terephftalate during storage and microwave heating. J PLASTIC film sheet 32(2):189-207

Willis K, Maureaud C, Wilcox C, Hardestly BD (2018) How successful are waste abatement campaigns and government policies at reducing plastic waste into the marine environment? Mar Policy 96:243-249

WWF, 2018. The lifecycle of plastics. [Online] Available at: https:// www.wwf.org.au/news/blogs/the-lifecycle-of-plastics\#gs.6yacyw [Accessed 205 2,020].

WWF, 2019. [Online] Available at: http://assets.wwfit.panda.org/downloads/fermiamo_inquinamentoplastica_giu2019.pdf

Publisher's note Springer Nature remains neutral with regard to jurisdictional claims in published maps and institutional affiliations. 